\title{
Antropofagia ritual e identidade cultural entre os Tupinambá ${ }^{1}$
}

\author{
A done A gnolin ${ }^{2}$ \\ Pós-doutorando do D epartamento de H istória - USP
}

RESUMO : A alimentação do homem é um dado altural que tem uma importância pelo menos igual àquele pura e simplesmente alimentar. Reservando uma atenção particular à relação que encontramos, entre dado cultural e dado alimentar/ "natural", o presente artigo levará em consideração o fato de que estamos falando de um alimento muito particular: trata-se do homem que se torna, dentro de uma estrutura altamente ritualizada, alimento para outro homem, o qual, por sua vez, vive na perspectiva, altamente significativa para sua cultura, de se tornar, um dia, ele mesmo alimento para os outros.

Pelo fato de reconhecer a importância do dado cultural no que diz respeito à alimentação do homem, aAntropologia se apresenta como perspectiva de análise imprescindível. Por outro lado, ela constituiráo esboço deum estudo crítico sobre sua própria caraterística de compreensão/ digestão da alteridade cultural.

Além do mais, a colocação da antropofagia ritual ("sagrada") no centro de nosso trabalho nos impõe o ponto de vista de uma metodologia de estudo históricoreligiosa. A utilidade dessa perspectiva de estudos está toda contida na adjetivação "ritual", que acompanha esta forma específica de antropofagia. Trata-se, conseqüentemente, de esclarecer esses termos/ conceitos (aos quais a escola históricoreligiosa tem dedicado tanta atenção), muitas vezes assumidos de forma acrítica, oferecendo uma significativa contribuição eproblematização aos estudos históricos e antropológicos contemporâneos.

0 presente texto propõe, portanto, uma análise da antropofagia no Novo Mundo nos séculos XVI e XVII, em relação a uma perspectiva, a indagação antropológica, problematizada por uma metodologia de indagação: a História das Religiões. Para tal debate, entendemos nos referir àquela que é conhecida pelo nome de "Escola Italiana de História das Religiões" e que se reconhece no trabalho pioneirístico empreendido por Raffaele Pettazzoni e proficuamente levado para frente por Brelich, De Martino, Lanternari, Sabbatucci, Massenzio.

PALAVRAS-CHAVE: Culturas Tupi, Antropofagia, História das Religiões, sacrifício, ritualidade, lógica do mito, trocas ritualísticas. 


\section{Introdução}

Selvagens e insaciáveis comedores de carne que habitam as margens mais extremas da sociedade ocidental: até o fim do século XV o termo "antropófago" manteve inalterado seu próprio significado clássico. Mas, ao encerrar-se o século XV, a extraordinária descoberta dos selvagens do Novo Mundo amplia, de maneira aparentemente ilimitada, tanto as possibilidades das descobertas geográficas, quanto o número dos selvagens, habitantes das novas, imensas fronteiras da cultura.

Além do mais, essa descoberta torna evidente 0 fato de que, ao redor da prática antropofágica americana, começa a tecer-se um sistema de traduções - tanto da alteridade americana em face da Europa, quanto das novas e inquietantes alteridades culturais européias - que contribui para que as considerações sobre a colonização da América se tornem, por exemplo, um pretexto para os propagandistas da fé católica porem a nu os horrores da Reforma. De fato, a Europa torna, na esteira da Antigüidade clássica, a falar de si através da imagem dos gentios bárbaros que teimam em comer carne humana.

Como já vimos em um trabalho nosso (Agnolin, 2000:XXI-XXXIII), os próprios $\mathrm{E}$ nsaios de Montaigne encontram uma parte consistente de sua inspiração, na tentativa de relativização da cultura européia, justamente nessa "utilização", muito peculiar em sua época, da nova alteridade americana.

Em seu trabalho Le cannibale, Lestringant relê, ao longo de uma bela análise diacrônica, a mudança que acompanha essa imagem do canibalismo na Europa, de Colombo até a época colonial. Sintetizando esse percurso cultural europeu, ele ressalta como

a degradação da imagem do outro, desde a idealização heróica da Renascença até os crepúsculos tempestuosos do romantismo, se acompanha durante 0 mesmo peńodo de umaincompreensão crescente da antropofagia. Ao modelo de explicação através do rito, que é o primeiro, se substitui logo, em nome da filosofia e da ciência, um esquema determinista que restabelece a prática à matéria e 0 costume à sujeição natural. Vítima de um meio ambiente hostil 
Revista de Antropologia, São Paulo, USP, 2002, v. 45 noํ 1.

e perdendo toda sua liberdade, o canibal não é mais do que um ser que come, um predador sem consciência e sem ideal, que, no caso de extrema escassez de víveres, vira seu apetite contra seus semelhantes. (Lestringant, 1994: 30)

O objetivo do presente artigo não é aquele de acompanhar as mudanças diacrônicas dessa imagem. Todavia, pelos objetivos de nosso trabalho, vale a pena evocar como é no interior desse percurso que se coloca um dos exemplos mais significativos de certa antropologia contemporânea: trata-se da interpretação dessa prática proposta pelo materialismo cultural. É justamente em contraposição a certas "determinações materiais" sustentadas por essa escola que podemos colher, de forma significativa, a peculiaridade da perspectiva histórico-religiosa proposta por nosso estudo. Para começar, segundo essa perspectiva de estudos, a prática alimentar não é condicionada aprioristicamente pelo seu valor nutritivo. De fato, os próprios cronistas - aos quais entrega-se o materialista (cultural) Harris $(1977,1985)$ - viajantes e missionários nos oferecem uma resposta que contrasta com esta instância materialista.

Não é prazer propriamente que as leva[as mulheres] a comer tais petiscos, nem 0 apetite sensual, pois de muitos ouvi dizer que não raro a vomitam depois de comer, por não ser o seu estômago capaz de digerir a carne humana; fazem-no só para vingar a morte de seus antepassados e saciar o ódio invencível e diabólico que votam a seus inimigos. (Abbeville, 1975: 233)

Eles fazem assim não para satisfazer a própria fome, mas por hostilidade, por grande ódio... (Staden, 1974: II, cap. XXV)

O s índios respondiam, portanto, estar agindo dessa forma somente para vingar a morte dos próprios parentes e destacavam que a vingança de sangue era só e único motivo das próprias expedições guerreiras. Além disso, é interessante observar que esses mesmos índios viam no apodrecimento dos corpos uma ameaça, culturalmente significativa. É, justamente, a esse respeito que se torna pelo menos curioso um paralelo antigo que, com a testemunha de Heródoto, ecoa uma representação análoga dessa ameaça entre os massagetes. Entre esses últimos, 
quando um torna-se velho, todos os vizinhos encontrando-se o sacrificam [...] e cozidas as carnes, banqueteiam. Isso eles estimam beatíssimo; e aquele que morre por causa de doença eles não comem, mas enterram, reputando desgraça que não tenha chegado ao sacrifício. (Mustodixi, 1820: 126)

Segundo o comentário a Heródoto do século XVI, o apodrecimento e o "banquete dos vermes" são tidos como a "má sorte", tanto temida. 0 mesmo ocorre entre os Tupinambá: nas testemunhas dos viajantes no Novo Mundo, Tommaso G arzoni escreve que "os massagetes comiam os próprios parentes mortos parecendo-lhes mais honesta sepultura 0 estômago do homem, do que o dos vermes" (Garzoni, 1587: 446).

$\mathrm{Na}$ leitura da prática antropofágica proposta nesta época, parece destacar-se, de fato, uma apropriação, tanto fisiológica quanto cultural, sem que isto represente uma contradição. Fica claro que esta apropriação cultural é diferentemente representada dependendo se trate de endocanibalismo (como neste caso e em alguns casos das culturas indígenas americanas) ou de exocanibalismo (como no caso tupinambá). Resta, contudo, o fato de que o homem se representa digerindo culturalmente a morte do outro, subtraindo-0, desta forma, ao desaparecimento, numa ameaçadora e anônima (para a cultura) dimensão natural. Nesta contraposição (alimentar) é curioso observar que, no testemunho do século XVI acima citado, a contraposição da natureza ao homem é quase parodiada, elevando a natureza à sua própria (contrastiva) dimensão cultural. Fala-se, de fato, de "banquetede vermes", como se esses últimos pudessem constituir uma sociedade particular, capaz de ser representada por uma das expressões mais significativas da cultura: 0 banquete.

O homem pode, edeve, subtrair seu semelhante a essa outra dimensão natural, a tal ponto ameaçadora da cultura (da memória), que quase pode constituir-se como uma outra cultura no seu "ser uma contra cultura". Parece-nos, portanto, que o depoimento levado em consideração evidencia quase uma disputa, uma contenda da morte entre a natureza - anônima, sem memória, uma "antropófaga" que tudo engole, sem nada preservar - e a cultura - identidária, que constrói a memória e faz do sacrifício antropofágico uma forma de preservação do outro. 
Revista de Antropologia, São Paulo, USP, 2002, v. 45 no 1.

Torna-se portanto evidente como, nessa perspectiva, a natureza nunca se configura (culturalmente) como dimensão meramente natural, materialista, mas é sempre, e de diferentes formas, construída em relação à cultura com a qual interage.

D essa maneira, o materialismo cultural entra em crise se conseguirmos demonstrar que "o valor de uso não é menos simbólico ou menos arbitrário que o valor-mercadoria. Porque a 'utilidade' não é uma qualidade do objeto, mas uma significação das qualidades objetivas" (Sahlins, 1976). Levando em consideração esses problemas, no seu ensaio C ultura e utilidade, Marshall Sahlins encontra em Morgan os princípios de uma pesquisa antropológica caracterizada por certa ênfase sobre as razões utilitaristas na análise dos fatos culturais. Esta ênfase encontra sua realização completa, segundo ele, na teoria da cultura elaborada por Malinowski.

Com esse trabalho, Sahlins teve o mérito de chamar a atenção para um problema de grande importância, evidenciando os riscos que são implícitos na tendência de fazer da categoria do útil o prisma interpretativo de fatos culturais, principalmente quando isso for feito em termos etnocêntricos. De fato, essa tendência "condena a uma função servil o aparato simbólico e os processos mítico-rituais, quer dizer, o inteiro horizonte religioso" (Massenzio, 1994: 178). De fato, se

é no domínio do econômico que tem lugar a primeira forma de valorização cultural da realidade, [...] isto não deve comportar [...] a absolutização do econômico, seu substituir-se a todo o restante, visto que um tal ultrapassar os confins seria contrastante com a própria função de valorização atribuída ao econômico. (: 180)

A relação entre valor nutritivo e valores simbólicos é, portanto, um mecanismo complexo que responde à complexidade das hierarquias sociais e a reforça. Q uanto mais o rito alimentar assume esta configuração complexa, tanto mais carrega-se de valores simbólicos dificilmente subordináveis ao valor nutritivo. 0 condicionamento que recebemos deste retículo simbólico oculta e condiciona nossas escolhas alimentares, 
ao ponto em que os alimentos e as práticas alimentares, diferentes das nossas preferências culturalmente dadas, podem provocar um tal desgosto, de outra forma não compreensível. O próprio "choque cultural" do explorador, do etnólogo, do missionário ou do colonizador, enfim do "estrangeiro", em face de uma desconhecida (no sentido de não reconhecida) etiqueta, transforma a diferente prática alimentar em um signo de "barbarização", de ausência de civilização ou, pior ainda, faz dela o signo privilegiado da ausência de humanidade.

Além de suas proteínas simbólicas, tanto a alimentação quanto a prática antropofágica que nos interessa de perto são marcadas por sua ritualidade. O ra, por um lado é verdade que existe uma grande produção bibliográfica acerca da antropofagia/ canibalismo; por outro, grande é a influência que as práticas antropofágicas americanas e a literatura por elas alimentadas - com destaque maior para as tupi - exerceram sobre esses estudos ${ }^{3}$.

Porém, o que detectamos como lacuna nesses trabalhos é, justamente, a inconsistência, muitas vezes a total ausência, de uma análise do aspecto ritual dessa prática. E, de fato, falar em ritualidade significa necessariamente abordar aquele "sagrado" que se dá não tanto como realidade sólida, objeto constituído de uma vez por todas, mas como relação historicamente determinada e nunca definitivamente dominada que necessita ser sempre culturalmente refundada, para ser reatualizada. D esse ponto de vista, a metodologia e os instrumentos teóricos da História das Religiões nos permitem uma abordagem inédita dessa problemática, utilizando o instrumento da comparação em sua riqueza e peculiaridade, isto é, para além dos limites em que se constituiu em alguns autores 4 .

Nessa perspectiva, os rituais de captura, de "construção" da afinidade (do prisioneiro com a sociedade que o recebia), de execução, de restauração do equilíbrio da cosmologia indígena Tupi (através do mecanismo da vingança), de renomeação do executor mostram a complexa elaboração simbólica do ato de comer do canibalismo Tupi ${ }^{5}$. 
Revista de Antro pologia, São Paulo, USP, 2002, v. 45 no 1.

\section{O sacrifício como fundamento da cultura}

Justificar a nutrição à base de carne sem, com isso, dever identificar-se com os animais carnívoros: este é o problema que, segundo Sabbatucci (1965), cada cultura colocou-se, para poder absorver essas importantes proteínas que trazem consigo, necessariamente, sua contribuição cultural e identitária. Tomando-se rito expiatório por excelência nos politeísmos antigos, 0 sacrifício, que envolve os deuses na ação humana, funda uma cultura. Eventualmente, como Sabbatucci evidenciano caso grego, estefundamento da condição humana pode ser rejeitado em bloco (mas sempre em uma relação dialética com aquela cultura) e, então, o vegetarianismo se constitui como rejeição da condição humana.

O utras culturas resolveram o problema reservando-se uma interdição alimentar em relação a determinados animais (D ouglas, 1976: 57-74; Tambiah, 1995: 195-250) ou construindo uma equiparação entre (ou seria melhor dizer "trocando") ceifa e matança, fazendo da matança uma coleta. Sobretudo, se o animal écolhido em seu valor "outro" ou "sagrado", a caça se configura, por isso, como um sacrilégio (Lanternari, 1974: 469), "como apropriação não devida de alguma coisa que se coloca na dimensão do extra-humano" (Massenzio, 1994: 82). Nesse último caso, muitas vezes, a presa da caça é denotada pertencendo a uma figura sobrehumana: 0 "Senhor" ou, mais freqüentemente, a "Senhora dos animais" se configuram como proprietário(a) e garantidor(a) da realidade animal, e a essa entidade a presa capturada deve ser restituída, em forma de "oferta primicial" (Brelich, 1966: 45-6), espécie de contradádiva à qual não se pode fugir sem correr o risco de comprometer as relações com essa realidade animal.

As precauções dos caçadores durante a caça, isto é, a ritualização de tal operação tão fundamental e tão perigosa, ao mesmo tempo, para o homem; os rituais de purificação na volta à aldeia que, enquanto permitem romper as ligações estabelecidas com essa outra dimensão extra-humana (a da floresta), por outro lado têm o objetivo de repristinar as ligações sociais dentro da dimensão humana (o vilarejo) (Lot-Falck, 
1953: 170-218); a necessidade de recorrer, em determinadas ocasiões, ou em relação à morte de determinados animais, a ritos expiatórios: todos esses aspectos demonstram o quanto é percebida como perigosa essa incursão nesta esfera extra-humana específica e, em conseqüência, o quanto é importante a função intermediária e protetora do ritual que, unicamente, pode oferecer-se como instrumento cultural fundamentalmente apto a construir e administrar aquela relação ao mesmo tempo "sacrílega" e, contudo, tão fundamental para o homem.

\section{A relação mito-lógica}

Uma interessante afirmação do tupinambá Cunhambebe feita a Hans Staden, e por este último relatada, é destaque na parte final da etnografia sobre os arawetés proposta por Viveiros de Castro ${ }^{6}$. Sem a pretensão de julgar criticamente como um todo sua complexa obra, gostaríamos de acompanhar e rever alguns pontos da sua análise conclusiva sobre a cultura Tupinambá.

D urante isto Cunhambebe tinha à sua frente um grande cesto cheio de carne humana. Comia de uma perna, segurou-a diante da boca e perguntoume se também queria comer. Respondi: "Um animal irracional não come um outro parceiro, e um homem deve devorar um outro homem?". Mordeua então e disse : "Jauára ichê". Sou um jaguar. Está gostoso7. (Staden, 1974)

Tenha sido ou não uma "tirada humorística" tupinambá, como sugeriu Viveiros de Castro, essa resposta de Cunhambebe resulta significativa, segundo o autor, da diferente ótica cultural dos dois protagonistas do episódio. Falando da própria ação canibalesca, o guerreiro determinou a perspectiva cultural da própria ação. Ele era um jaguar enquanto 0 próprio alimento era um homem. Se a perna que estava comendo pertencia a um inimigo, a boca que a devorava devia ser aquela do inimigo por excelência, o jaguar, "canibal" não comestível.

Naturalmente, diz-nos Viveiros de Castro, tratava-se de um jaguar que possuía o fogo (sacrificial), um "jaguar civilizado": comia carne 
Revista de Antropologia, São Paulo, USP, 2002, v. 45 no 1.

cozida (moqueada). D esta forma a antropofagia de Cunhambebe não era uma alelofagia (devoração do semelhante), como pensava Staden, nem uma omofagia (comer cru) (Viveiros de Castro, 1986: 625) ${ }^{8}$. A sua antropofagia era um "tornar-se fera", mas com a posse e o domínio do fogo. " $\mathrm{O}$ 'modo de falar' de Cunhambebe determinava seu modo de comer, que era modo de pensar"; tornar-se jaguar, além disso, parece, mais "uma qualidade do ato, não do sujeito" (: 626).

Sem dúvida, de acordo com o autor, esta linguagem toma-se metáfora para nós, assim como foi para Staden. Ao mesmo tempo ela nos oferece também a oportuna confirmação de que o canibalismo tupinambá implicava, pelas próprias pessoas que o praticavam, um comportamento de animal selvagem e feroz: 0 do jaguar 9

Se, como para 0 autor em consideração, uma análise antropológica da cultura indígena não pode parar ante uma constatação da metáfora lingüística, é importante, para nós, perguntarmos o que significa "jaguar" na cultura mitopoéica Tupinambá. Para fazer isso, não podemos utilizar a nossa significação de "jaguar", mas devemos tentar alcançar essa significação (até onde for possível) dentro do "fazer mitológico" próprio da cultura Tupi. Portanto devemos eventualmente analisar quais são as versões míticas nas quais encontramos descrita (de modo performativo para as culturas indígenas) a função mitológica do jaguar (panthera [Jaguarius] onça) - e com ele da antropofagia - para os Tupinambá.

Não será possível propor uma indagação exaustiva das numerosíssimas versões míticas nas quais se inscreve a ação mítica deste precioso instrumento cultural Tupi que é o jaguar. Por outro lado, a sua marcante presença, a sua importância e suas importantes funções culturais podem ser encontradas ao longo de toda a obra antropológica de Lévi-Strauss ${ }^{10}$. 0 que podemos fazer aqui é destacar, entre essas numerosas referências, algumas características que possam oferecer algumas trilhas: elas devem nos permitir seguir as pegadas do jaguar em sua função de instrumento cultural Tupi e procurar, através desse instrumento, algumas possibilidades de melhor entender o significado da prática antropofágica para a cultura Tupi. 
Começamos um esboço desse caminho, estabelecendo uma comparação que nos leva para outra área cultural americana, em companhia de um outro animal: o coiote (canis latrans). Na América do Norte, LéviStrauss encontrou esse animal como protagonista de vários mitos, assumindo as característica de um modelo intermediário entre herbívoros e carnívoros ${ }^{11} \mathrm{e}$ desempenhando a função de mediador (mito-)lógico entre duas maneiras de se alimentar, entre dois modelos de vida. Neste caso, porém, o coiote dos mitos representa um modelo ridículo e negativo que serve para valorizar a capacidade (cultural) do homem de transformar os bisões em alimento cárneo.

Às vezes, a contraposição entre esses dois regimes alimentares se constitui na contraposição (correlação) entre os dois sexos: assim, se a contribuição econômica do sexo feminino está baseada na coleta e a do masculino na caça, os homens são representados (isto é, "construídos" nos mitos) como carnívoros e as mulheres como herbívoras, independentemente da complexidade do sistema econômico-cultural.

Portanto, a sintaxe dessa classificação dos regimes alimentares evidencia como a distinção entre animais que matam (carnívoros) e que são mortos (herbívoros) estabelece uma apreciação comparativa dos dois regimes alimentares que encontram seu significado (e ao mesmo tempo contribui para dar-lhe significação) naquele sistema de valores que se chama cultura $^{12}$.

Partindo de algumas páginas do livro de Curt Nimuendajú sobre os Xerentes, na parte final do seu L e jaguar et le tamanoir, Bernard Arcand propõe uma leitura estruturalista ${ }^{13}$ de determinados mitos e rituais que envolvem essas duas figuras. Essa análise obtém uma contraposição muito significativa - para os X erentes, como para nosso trabalho - entre o jaguar e o tamanduá. Este último come muito pouco e pode sobreviver por muito tempo sem alimento; a sua boca não é uma verdadeira boca (trata-se, aliás, de um animal sem dentes) e, na outra extremidade, seu ânus é protegido por lábios que o escondem completamente: em conseqüência ele aparece como um animal "tapado" (nada entra nele, nada sai dele); os lábios, que escondem o ânus, ocultam também 0 
Revista de Antropologia, São Paulo, USP, 2002, v. 45 no 1.

pequeno pênis assim como os testículos: por esse motivo ele se mostra, ainda, como animal assexuado; sendo um animal de hábitos solitários, o seu aspecto exterior faz dele um símbolo da velhice, donde deriva a crença de que ele seja um animal imortal. Em síntese, sua falta de necessidade alimentar, sua descaracterização sexual, seu ser solitário fazem do tamanduá um ser a-social. Por outro lado, enquanto símbolo da velhice e da imortalidade, ele evoca os antepassados.

Em contraposição ao tamanduá, o jaguar é o carnívoro por excelência. G rande caçador, ele come muito e não tem o hábito de ficar por longo tempo sem comer. Ele é grande caçador de (faminto por) sexo, também: em todos os mitos aparece essa sua forte caracterização sexual. Contrariamente ao tamanduá, a sua propensão pela caça, seu apetite e sua sexualidade fazem do jaguar um ser fortemente social.

O ra,

os X erentes definem, em primeiro lugar, com clareza, [esses] dois modelos de vida, depois declaram abertamente querer viver como osjaguares. D e fato esse animal se parece tanto com eles que chega a constituir um ideal de vida ativa e produtiva: todo caçador quer possuir a sua habilidade; se diz que toda mulher o deseja para marido e que cada xamã deve ser capaz de se transformar em jaguar para poder cumprir seus milagres. 0 tamanduá, ao contrário, está associado aos antepassados e aos anciãos. O ferece a imagem de um modo de vida tranqüilo, sem apetite, a não ser quanto às formigas; uma vida com poucas exigências, durante a qual ele não pede nada aos outros e não quer fazer mal a ninguém. (Arcand, 1995: 293-94).

A cultura Xerente escolheu, portanto, explicitamente entre um autaut: "quem deseja ser um grande caçador, provido de bom apetite, sexuado e social tem que renunciar à longa vida (se não à imortalidade) tranqüila do tamanduá" (Arcand, 1995: 295). D essa maneira, para os Xerentes, a única esperança de escapar da morte se realiza somente através da reprodução, motivo pelo qual o jaguar é obcecado pelo sexo, enquanto 0 tamanduá precisa tão pouco dele.

Todavia, como evidenciado por Lévi-Strauss,

o jaguar e o homem são termos polares, cuja oposição é duplamente formulada na linguagem comum: um come comida crua; e, sobretudo, o jaguar come 0 
homem, mas o homem não come 0 jaguar. 0 contraste não é somente absoluto, mas implica, além do mais, que entre os dois termos intercorra uma relação fundada sobre a reciprocidade nula. Para que os bens de hoje do homem (que o jaguar não possui mais) possam vir do jaguar (que os possuía no passado, quando o homem era desprovido), é portanto necessário que entre o homem e o jaguar apareça um termo mediador: é, de fato, esta a função da esposa (humana) do jaguar. (Lévi-Strauss, 1991: 86-7)

Em Caminhos e fronteiras, Sérgio Buarque de Hollanda releva o perigo que 0 jaguar representava, tanto para os sertanistas quanto para os índios e afirma que "até pelo porte e aspecto, muitas delas [onças] parecem denunciar suas predileções antropofágicas. Assim, a magreza num jaguar passava geralmente por indício quase certo de antropofagia" (Hollanda, 1994: 92). Mas é de extrema importância observar, de acordo com o nosso autor, que, como relata Gabriel Soares de Souza (1971: 288), "entre esses índios [os antigos Tupi do litoral], o modo ordinário de caçar a onça era, ao que parece, por meio de mundéus ou fojos. Uma vez aprisionada é que a fera podia ser morta a frechadas. Em certos casos acabavam-na em terreiro, como aos contrários, tomando nome e fazendo todas as œrimônias da antropofagia ritual" (Hollanda, 1994: 94)14. E tudo isso, complementado pelo fato de que a carne do jaguar "não seria apetecida dos índios pelo seu sabor, mas antes pelo poder, que lhe atribuíam muitos, de comunicar força e coragem a quem a consumisse" (: 95); deve ser levado em consideração, também, o fato de que as próprias unhas e dentes do jaguaretê, como os dentes e ossos humanos, eram usados como "amuleto" a fim de afastar o portador de qualquer perigo.

Falando a respeito da necessidade de um homem (guayaki) superar um determinado estado ${ }^{15}$, para realizar-se como caçador ao arrancar caça da floresta, Clastres observa que, caso não tenha êxito em sua ação, "será ele mesmo a se tornar caça para esse outro caçador que é 0 jaguar". Assim, essa fera se configura como um concorrente do homem (pois mata os mesmos animais) e, além do mais, representa um animal que torna o homem, ao mesmo tempo, caçador e caça. 0 jaguar constitui uma ameaça à "humanidade do homem". Este último, para conservar a própria humanidade - nós diríamos, para "renová-la ritualmente" - , "deve 
Revista de Antropologia, São Paulo, USP, 2002, v. 45 no 1.

afirmar-se como caçador, como matador de animais" (Clastres, 1995: $22)^{16}$. E se 0 jaguar vinga "a quase todos os animais, quando os caçadores os flecharam" (: 196), ele parece configurar-se com o estatuto que é próprio do "Senhor dos animais" (mais freqüentemente da "Senhora dos animais") das sociedades caçadoras (Brelich, 1966: 19-20 e 45; Lanternari, 1974; Massenzio, 1994: 82ss).

Enfim, "há de algum modo um parentesco entre os mortos e essa metáfora de tudo que o mundo em volta contém de perigos mortais [...]: o jaguar". Por isso, se "os mortos são jaguares", os mortos "não somente são excluídos da comunidade dos vivos, mas esses os expulsam mesmo do mundo social da cultura, transformando-os em jaguares, rejeitando-os para o lado da natureza" (Clastres, 1995: 218).

Completando este breve ex aursus, encontramos a prova dessa posição singular que o jaguar ocupa no sistema tupinambá logo numa nota de rodapé do artigo "Vingança e temporalidade", de Carneiro da Cunha e Viveiros de Castro. Na página 66 desse artigo, os autores referem que, além da frase de Cunhambebe (eu sou onça) referida por Thevet, em sua "Relação da Província do Brasil", o jesuíta Jácome Monteiro disse que os índios pensavam que aquele animal houvesse sido gente, em outros tempos (Monteiro, 1949: 418). D a mesma forma constatamos, através da obra de Cardim (1980: 26), o fato de que o jaguar podia ser morto em terreiro - com conseqüente tomada de nome - e, através da obra de Thevet (1953b: 156), que havia o costume de 0 animal, depois de ter sido morto (quando preso na armadilha), ser trazido para o terreiro e paramentado "como um prisioneiro que irá ser comido". A respeito desse relato é, aliás, de extremo interesse a observação de que, endereçando-lhe um discurso que é o inverso do diálogo do cativo, pede-se-lhe que desculpe uma morte que não foi intencional e que, portanto, esquecendo essa morte, não queira se vingar dos homens. Para obter um "efeito de realidade" na constituição desta pia fraus e a fim de não se tornar vítimas da onça, mais uma vez, os Tupi se abstêm da devoração de suas carnes. 
O ra, essa relação cultural estabelecida com 0 jaguar ${ }^{17}$ nos parece ser uma maneira de construir a cultura (humana), diferenciando-a de uma "natureza" que é sempre culturalmente construída e na qual, portanto, até mesmo os mortos podem ser transformados. Enfim, desde 0 momento que a natureza é simbolicamente transformada, interpretada (e, gostaríamos de dizer, produzida, no contexto cultural), ela confunde suas características "naturais", materiais, com as do processo cultural que a interpreta. Assim, como no caso do "fenômeno cultural" da religião (à compreensão do qual nos convida Brelich), podemos dizer que a natureza, também, "não foi [...] - nunca e em nenhuma lugar - um 'dado de fato' [...], mas sempre e onde quer que seja [ela é], como a própria cultura, criação contínua". E se a conservação de determinados fundamentos de seus aspectos constitui um ontinuum, isso se deve, substancialmente, ao fato de que "nenhuma civilização cria ex nihilo, enquanto, por outro lado, a 'pura' conservação requer sempre novo empenho na contínua mutação das condições" (Brelich, 1969: 9).

A análise da função (mito-)lógica do jaguar para as culturas Tupi ${ }^{18}$ pode se tornarum instrumento útil de indagação tanto em relação à problemática da antropofagia, quanto no que se refere a essa relação natureza/ cultura. Isso, na medida em que "existe, de fato, um 'plano animal' na guerra [tupi]; os guerreiros inimigos colocam-se, muitas vezes, nas emboscadas, nas ciladas, tanto quanto nas cerimônias antropofágicas, em relações do tipo presa-caçador" (Fernandes, 1970: 44-5).

\section{A antropofagia e a boa morte do homem adulto}

A prática antropofágica constituía o momento culminante do processo cultural Tupi que encontrava na guerra e na execução ritual dos prisioneiros a meta e o motivo fundamental da própria identidade cultural.

Desde 0 momento da captura do prisioneiro ${ }^{19}$, as testemunhas dos viajantes, recolhidas por Métraux (1971), evidenciam uma dócil, e no 
Revista de Antropologia, São Paulo, USP, 2002, v. 45 no 1.

mínimo curiosa, aceitação de um destino que, portanto, configura-se como culturalmente previsto.

Montaigne evidencia uma apreciação estética a respeito da guerra tupinambá (exaltando sua "beleza"). Isto, devido às suas características (de "nobreza" e de "generosidade"). Tinha-se a "paixão pelo valor" (Remotti, 1996: 70), como fundamento exclusivo da guerra. Essa, mais do que uma divisão interétnica, vem a representar o compartilhar de um modelo cultural fundamentalmente unitário que, por ser unitário e, necessariamente, compartilhado, alimentava um sistema de reciprocidade. Em razão disso, tornam-se inutilizáveis, hoje, determinadas categorias históricas ocidentais que dão como pressuposto um espaço de decisão, de liberdade, de escolha, como as categorias utilizadas ${ }^{20}$ por Montaigne.

Nossa tentativa aqui, consistirá em uma "recuperação" do trabalho de Florestan Fernandes. Isso sem querer ocultar determinados limites (funcionalistas) da obra do autor que, com objetivos e instrumentos teóricos próprios, permanece, contudo, como um marco muito importante para qualquer etnografia Tupi. É com A organização social dos tupinambá eA função social da guerra na sociedade tupinambá21 que 0 sociólogo brasileiro se propõe a reconstruir a articulação funcional do complexo sistema da sociedade tupinambá, baseando-se no material deixado pelos cronistas.

Herdeiro de uma tradição de estudos fundada no (e, segundo o nosso ponto de vista, limitada pelo) funcionalismo, o referido autor analisa cada instituição ou "costume" com particular atenção voltada para seus múltiplos aspectos funcionais: isto porque procura demonstrar a subordinação, tanto da "organização ecológica" quanto do "sistema organizatónio" tupinambá, ao "sistema religioso" que constituía a fisionomia e a dinâmica de todo 0 sistema social. 0 funcionalismo dos diferentes aspectos culturais desta sociedade seria, portanto, subordinado à religião, fundada no culto dos antepassados e fundamento da guerra tupinambá. É por isso que o prisioneiro, antes de ser conduzido à aldeia, era levado 
ao túmulo da família de seu dono e era obrigado a "renová-la", "como se se tratasse de uma vítima que devia ser sacrificada em memória deles" (Thevet apud Léry, 1980: 193).

Para 0 autor, então, os Tupinambá não se beneficiavam tanto das energias do prisioneiro, e sim da substância do parente que aquele havia (eventualmente) comido e do qual eles buscavam a reapropriação. Tratarse-ia, pois, nos termos sociológicos caros a Fernandes, da recuperação da integridade da coletividade, projetada num plano religioso através da representação (tal como aparece para nós, ocidentais, hoje) de uma exigência (feita pelos próprios espíritos) das vítimas e de seu sacrifício. "O sacrifício não era causado pela ação dos inimigos, mas por necessidades do 'espírito' do parente morto por eles". Em conseqüência, ele

nascia da interpretação, por meios xamanísticos, da vontade dos "espíritos" dos antepassados e dos ancestrais míticos [...]. O sacrifício humano tupinambá possuía, por sua vez, a sua "dialética interna", a qual [...] constituía, do ponto de vista das relações com as entidades sobrenaturais, uma espécie de cadeia fechada, posta em movimento continuamente, por meio do massacre de vítimas sucessivas aos mesmos espíritos. (Fernandes, 1970: 319)

E, mais para frente, o autor sublinha: "enquanto o desejo canibalístico das divindades ou ancestrais míticos não fosse satisfeito, as parentelas sobre as quais caíam tais obrigações se viam sujeitas a perigos que só podiam ser evitados através da consumação do sacrifício sangrento": em conclusão, criava-se uma "cadeia circular de obrigações impostas imperativamente pela necessidade de estabelecer a relação sacrificial" (: 331). Isso também explicaria a relevância, para essa cultura, da figura dos pajés, os quais seriam, sobretudo, "intérpretes da vontade dos espíritos dos antepassados" (1989: 286).

Se a prática antropofágica constituía "um drama ritual de profunda importância religiosa e social" (Métraux, 1971: 52), conseqüentemente ela se configurava como instrumentum religionis (Fernandes, 1970: 160). A guerraé, portanto, interpretada como o mecanismo central da reprodução social e da manutenção do equilíbrio cultural Tupinambá, sobretudo no que se refere ao valor ambivalente da morte. 
Revista de Antropologia, São Paulo, USP, 2002, v. 45 no 1.

Concebida na base proposta pelo modelo do sacrifício de Mauss, a análise de Fernandes, sobre 0 sistema da vingança e so bre 0 significado da execução ritual, ressalta a função e a importância da "representação" do espírito do morto dentro do grupo que, no sistema "bélico-sacrificial", deve ser vingado. Finalmente, 0 autor coloca o complexo ritual numa função principalmente funerária dentro da qual o ritual antropofágico assumia uma função positiva: a morte do inimigo impedia a possível morte do grupo e, simultaneamente, constituía a única possibilidade de acesso dos executores ao status de pessoa, enquanto "adulto-matador".

De fato, o longo processo de ordem ritual que subentende à guerra, à captura de prisioneiros e a seu sacrifício, manifesta claramente um "princípio de reciprocidade" que perpassa a cultura Tupi e se constitui como fundamento da prática antropofágica. Nessa perspectiva, tanto a "indiferença" ostentada quanto a "resignação" do prisioneiro em relação à própria sorte ${ }^{22}$ têm seus fundamentos no compartilhar (por parte dos grupos antagônicos) esse princípio de reciprocidade sobre 0 qual se sustenta a segurança de serem, sucessivamente, vingados pelos próprios "parentes". E, nesse sentido, a capacidade de se vingar significaria a capacidade de reafirmar a própria identidade contra o inimigo. Portanto, nas culturas Tupi, "o 'caçador' e o 'guerreiro' coexistiam de fato nos tipos de personalidade masculina cujo status fosse de 'homem adulto' (avá ou tujuáe)" (Fernandes, 1970: 46).

Neste ponto, é interessante observar que, dentro deste "princípio de reciprocidade", assume um valor extremamente significativo o fato do cumprimento, digno e glorioso, da vida de um guerreiro consistir em ser assimilado pelo corpo vivente do inimigo. A própria documentação dos viajantes e exploradores europeus dos séculos XVI eXVII evidenciava como 0 estômago do inimigo representaria 0 único túmulo digno de um guerreiro tupinambá: sem a morte em mãos de outrem ter-se-ia paralisado o mecanismo interminável da vingança que constituía, aliás, a garantia da reprodução social, determinando a possibilidade do acesso ao status de pessoa na cultura Tupi. 
E não pensem que o prisioneiro se abale por causa dessas notícias [de ser devorado em breve], tem-se a opinião de que sua morte é honrosa, e que lhe vale muito melhor morrer assim, do que em sua casa por causa de uma morte contagiosa qualquer: porque, dizem eles, não se pode vingar a morte, que ofende e mata os homens, mas se pode muito bem vingar aquele que foi morto e massacrado em proeza de guerra. (Thevet, 1953b: 196)

Se a morte se configurava como destino comum, por outro lado distinguia-se uma morte "boa" de uma "ruim" (em guerra ou em casa), assim como assumia grande importância a condição individual do morto (homicida ou não). $\mathrm{Na}$ primeira série de termos entrevemos uma apropriação cultural da morte, motivo fundamental do ordenamento cultural, contraposta a uma morte natural desonrosa.

Uma das funções centrais do canibalismo consistia, portanto, em adquirir uma condição humana justamente através de um controle e de uma conquista cultural da morte, criados em torno da representação do inimigo, dos ritos sacrificais e das práticas alimentares antropofágicas. Controle da morte que opera em direção de uma construção e afirmação da identidade. Contudo, entre os Tupi, a morte pode configurar-se culturalmente administrável só na condição de uma "representação" que envolve uma oposição, da qual a guerra e a vingança marcam as fronteiras, definindo, dessa forma, os "nós" e os "outros": nesta perspectiva, é importante observar, o canibalismo não envolve as unidades particulares numa recíproca unidade sem solução de continuidade ${ }^{23}$.

E tudo isso porque tratava-se de uma atividade profundamente ritualizada. De fato, como no ritual antropofágico,

o "ciclo de guerra" na sociedade tupinambá era dotado de ritmo regular: os ritos estabeleciam com precisão o que os indivíduos deviam fazer no curso dos acontecimentose situações sociais, que se desenrolassem entre a determinação do ataque e a consumação do sacrifício dos inimigos aprisionados. A rigor, todas as atividades guerreiras faziam partedeum conjunto de ritos, organicamente integrados einterdependentes. Nele também se integravam os ritos de sacrifício do inimigo, de antropofagia e de renomação. (Fernandes, 1970: 67-88)

A identidade cultural Tupi é sempre, continuamente, posta em jogo pela alteridade - ritualmente determinada e controlada - a qual, por 
Revista de Antropologia, São Paulo, USP, 2002, v. 45 no 1.

conseqüência, constitui necessariamente o próprio núcleo da identidade. Assumir essa "identidade na alteridade" delineia, portanto, a característica que responde, de forma plena, ao modelo cultural indígena. É somente assim que os "guerreiros" tinham acesso ao mundo dos mortos, com as divindades e os heróis civilizadores. Interessante é a caraterização lingüística indígena: os mortais comuns (mortos de morte natural) são "verdes", "crianças", afinal "crus". É necessária a morte (ritual) e 0 cozimento (sacrificial) para que amadureçam, cresçam e se completem. $\mathrm{E}$, antes disso, os "viventes" tornavam-se "homens" (avá) só quando tivessem conseguido aprisionar um inimigo e sacrificá-lo ritualmente: isso constituía o pressuposto que criava "o direito de passar pelos rituais que dariam acesso ao status de 'homem'” (: 149) ${ }^{24}$, que se configurava, claramente, como status ondicional.

Nesta relação, cultural e ritualmente determinada, conseguia-se uma continuidade da função cultural também na perspectiva da vítima. Portanto, se, no olhar de um europeu, as evasões eram desencorajadas porque, "se um prisioneiro fugisse, seria tido em sua terra por 'cuave eim', isto é, poltrão, covarde, e morto pelos seus, entre mil censuras por não ter sofrido a tortura e a morte junto dos inimigos, como se os da sua nação não fossem suficientemente poderosos e valentes para vingá-lo" (Abbeville, 1975: 230-31); por outro, do ponto de vista indígena, não se pode tratar de nobreza ou generosidade no caso da "aceitação" de seu destino, assim, no caso contrário, não se pode tratar de covardia. Não existiria, de fato, uma aceitação (ou uma rejeição) não existindo uma alternativa para o prisioneiro, que via na própria morte a sua única forma de vingança/ afirmação de identidade. Na perspectiva antropológica, a única alternativa que se determinaria seria aquela de um simples "não ser" (eventualmente, homem).

Logo, desse ponto de vista é absolutamente compreensível que, "como estes cativos vêem chegada a hora em que hão de padecer, começam a pregar e dizer grandes louvores de sua pessoa, dizendo que já estavam vingados de quem os há de matar" (Souza, 1971: 326): isso 
porque já tinham matado e comido muitos inimigos e, além disso, teriam sido vingados pelos seus parentes vivos. A morte da vítima representava, portanto, a única possibilidade de se vingar da morte, através de uma absoluta cumplicidade entre vítimas e executores, que garantia a constituição da identidade (cultural) Tupi. E se a morte representava essa garantia para a vítima, através de sua "vingança da morte", para os executores, de fato, matar e devorar um inimigo representava por um lado a vingança (cúmplice da primeira), e por outro tornava seguro aos jovens 0 acesso à condição de guerreiro (homicida), isto é, de pessoa completa, madura (iniciada).

E os dois processos significavam, no fundo, a mesma coisa: a construção da identidade através da atribuição do status social de adulto. Esse aspecto vem colocando em cena 0 fato de que, sem ter antes matado um inimigo, o homem (cultural) não existia! Isso significa que a execução ritual se configurava como uma autêntica cerimônia iniciática masculina. De fato, as iniciações, "se fundam sobre uma norma social: a comunidade tem a intenção de transformar, através das iniciações, indivíduos ainda não 'normais' em indivíduos 'normais', isto é, que correspondam à sua norma [...]. [Por conseqüência] serem 'adultos' não somente não é um fato fisiológico, [...] nem mesmo somente um fato social, mas um fato cultural" (Brelich, 1969: 24). Nessa direção, o sacrifício ritual tupi assume as características que são próprias dos rituais iniciáticos: constituía 0 homem omo produto altural.

D essa maneira somente aquele que tinha antes matado um inimigo poderia se casar e ter filhos. Isso explica porque, entre os Tupinambá, a função de matar, própria dos guerreiros, e a reprodutiva, das mulheres, eram estritamente correlatas ${ }^{25}$, como destacou o próprio Thevet, falando sobre os ritos iniciáticos. Por isso as viúvas, cujos maridos tinham sido mortos em guerra, não podiam se casar de novo antes que aqueles não tivessem sido vingados; porém, podiam ser cedidas como companheiras ao prisioneiro para "recompensar a perda do próprio defunto marido [...] isto tira elas da tristeza e do tédio" (Thevet, 1880: 283). 
Revista de Antropologia, São Paulo, USP, 2002, v. 45 no 1.

Esta correlação entre função homicida e função reprodutiva torna manifesta uma exigência própria do "pensamento mítico". Como ressalta o próprio Lévi-Strauss (1967a), uma vez evidenciada a existência de determinadas oposições de significado, verifica-se a tentativa de estabelecer uma "mediação progressiva" 26.

D o ponto de vista da vítima, a execução, o cozimento e a devoração representavam operações que, libertando-a da putrefação, a subtraía ao desaparecimento na natureza, para assumi-la (assimilá-la) na dimensão cultural. Além disso, a sua morte constituía a sua própria vingança contra os que deviam matá-la e comê-la: e isto, seja porque teriam tido que assimilar (indiretamente) seus próprios "parentes" mortos por ela, seja porque os parentes vivos da vítima a teria, por sua vez, vingada. Reencontramos, pois, intacta a oposição levistraussiana entre cru e cozido, que opera no eixo da cultura, e entre fresco e pútrido, que opera no eixo da natureza. E se, geralmente, o cozimento cumpre a função de transformar (culturalmente) o cru, assim como a putrefação tem a de transformá-lo (naturalmente), a estrutura vale como indicador da máxima, levando em consideração que "os Tupinambá diferiam dos Guarani e da maior parte dos outros Tupi do mesmo modo que os outros Jê diferem dos A pinajé, isto é, situando o problema da vida breve numa perspectiva sociológica e não cultural" (Lévi-Strauss, 1991: 184).

Nesta "lógica das qualidades sensíveis" tornamos, portanto, a falar sobre as proteínas simbólicas dos valores culinários - representadas por Lévi-Strauss através das modalidades de assumir os alimentos (cru/ cozido, fresco/ pútrido... ${ }^{27}$ - , da articulação e determinação social e cosmológica estabelecida por esses valores simbólicos - articulação entre afins/ inimigos, homens/ divindades... - para, enfim, entre termos que não têm uma correlação possível de significados - visto que parece impossível a "passagem" conceitual entre vida/ morte, identidade/ alteridade... - tentar estabelecer uma "mediação progressiva" que na intermediação (cultural) permita a reapropriação das oposições de significados. 


\section{A troca cultural}

A transformação do prisioneiro em alimento representa uma cosmologia indígena que diz respeito a uma descontinuidade no processo de aproximação das duas sociedades envolvidas nessa "troca ritual". Isto porque:

1) A alteridade não se come "crua". 0 outro nunca pode ser absolutamente outro. "Introduzindo-se cada vez mais na sociedade que o 'hospeda', muda a atitude dos vencedores: das iniciais explosões de ódio e de desejo de vingança (sobretudo por parte das mulheres, essa 'outra alteridade' dentro da sociedade Tupi) se passa a manifestações de benevolência, senso de hospitalidade e até mesmo de afeto e intimidade" (Remotti, 1996: 77) para com o prisioneiro. Veja-se, a esse respeito, a disposição, por parte do dono, na doação de uma irmã sua, de uma filha ou de uma mulher secundária ao seu escravo, ou sua disponibilidade em se sacrificar para mantêlo. D efato, "as ligações que uniam um homem a um prisioneiro eram julgadas motivo de honra" (Métraux, 1971: 56-7). Gozando de uma liberdade relativa e sendo-lhe entregues os bens que foram de um guerreiro morto, o prisioneiro é, de fato, introduzido na sociedade vencedora, colmando, assim, os vazios produzidos pela guerra. A partir dessa fase ele alimenta identidade, parcialmente corrompida, da sociedade que o hospeda. A alteridade do outro já não é mais uma alteridade totalmente "crua", ele não é mais (não pode ser) totalmente outro, mas se configura como "uma alteridade domesticada, introduzida, assimilada, representada por um prisioneiro que, pela liberdade da qual goza, pelos bens de que usufrui, pelas atividades que desenvolve, é 'quase como se fosse' um de 'nós'" (Remotti, 1996: 78). Não podendo comer uma alteridade totalmente crua, as passagens rituais ao longo do tempo atuam uma transformação do inimigo que representa um verdadeiro cozimento (domesticação) desta sua alteridade.

2) A assimilação do prisioneiro representa um riso constante, na medida em que a operação de domesticação corre o risco de apagar a sua diferença. A fim de evitar esse perigo, assumem uma relevante significação os 
Revista de Antropologia, São Paulo, USP, 2002, v. 45 no 1.

periódicos rituais redefinidores de sua condição de inimigo, destinado ao sacrifício. Métraux lembra a esse propósito, através de Thevet $(1953)^{28}$, os rituais durante os quais "cada um indicava sobre a pessoa os pedaços aos quais aspirava", ou as ocasiões nas quais "era também obrigado a passar em parada pela aldeia, sumptuosamente decorado de ornamentos de plumas, enquanto jogavam contra ele plumas de papagaio, rito que, parece, significava que a sua morte era inelutável" , ou a mesma função reservada aos "colares que os prisioneiros eram obrigados a usar [e que] indicavam a duração de tempo que ainda tinham para viver" (1971: 58).

Este "princípio de reciprocidade" faz que os inimigos não sejam simplesmente os outros ou, parece possível dizer-se (sem com isso querer criar um jogo de palavras), que os outros não se configuram simplesmente como inimigos. D e fato, eles representam também "aqueles entre os quais é honroso morrer, pelos quais é um bem ser assimilados e incorporados, nos quais é coisa prestigiosa e plena de valor serem sepultados" (Remotti, 1996: 81). E, como dizíamos, tratar-se-ia menos de um valor individual do que social, representativo de uma característica forma cultural de construir a própria identidade.

Na ação final de assimilação antropofágica, através dos procedimentos rituais, manifesta-se de modo evidente a bipolarização identidade/ alteridade que acaba reforçando a alteridade do inimigo que se torna, enfim, comida para os outros. Falamos da descontinuidade do processo ritual e agora podemos, de fato, verificar que "o prisioneiro B é comido num momento em que a sua assimilação a A [o grupo que o capturou] foi levada até um ponto crítico que, se fosse superado, teria tornado impossível matá-lo. 0 ponto crítico é aquele no qual ao prisioneiro foram consentidas ou impostas quase todas as experiências culturais e sociais de A" (: 84).

Podemos perceber, portanto, que as práticas alimentares ameríndias, não diferentemente daquelas ocidentais, além de movidas por necessidades alimentares (nutricionais), são caracterizadas por determinações 
culturais. Tornam-se, então, operadores lógicos que têm a finalidade de organizar e determinar (e, assim, de discriminar também) a realidade cultural. D essa forma, o canibalismo adquire, também, um significado peculiar em relação à determinação cultural de sujeitos, culturalmente, determinados.

Por tudo isso, se "a festa e o rito funerário produzem, exibem e controlam aquilo que a vida quotidiana se esforça por ocultar ou ignorar: a aliança e a diferença, a impossibilidade de uma perfeita autonomia", por outro lado, "quem come [...] é sempre um outro, que se constitui como outro exatamente no ato de comer; mas o que é comido é, por este ato mesmo, produzido como um outro. 0 que se come aqui é sempre relação; relações comendo (relacionando) relações" (Viveiros de Castro, 1992: XVIII).

Esse fato determina a configuração do exocanibalismo tupinambá, tanto como opressão e destruição do outro, quanto como assimilação e conservação da alteridade. De fato, "os ossos [o que 'sobrava' do inimigo feito alimento] eram conservados como troféus ou transformados em flautas e em assobios. E os crânios plantados sobre paus na frente da cabana do matador eram prova do seu valor" (Métraux, 1971: 77). Além do mais, alimentar-se dessa alteridade não significava a sua destruição literal, mas representava significativamente a sua transformação: quem comia adquiria a substância da alteridade que, por outro lado, ia configurarse, por sua vez, como o túmulo (cultural) que lhe teria permitido subtrairse a uma desonrosa morte na natureza.

Esse processo vem portanto a constituir uma recíproca transformação, tanto de quem é assimilado, quanto de quem assimila, levando o guerreiro Tupi a se aproximar da condição de antepassado ${ }^{29}$ (a outra alteridade na dimensão temporal) através do estrangeiro.

Em conseqüência - assim como sugeriu de maneira interessante a esse respeito a análise proposta por Viveiros de Castro (1986: 650), embora tendo retomado o que Fernandes já havia evidenciado (1989: 105-8 $)^{30}$ - a prática antropofágica inscreve-se em diferentes registros culturais. Parece delinear-se, em primeiro lugar, um canibalismo restaurador 
Revista de Antropologia, São Paulo, USP, 2002, v. 45 no 1.

que anula a "heteronomia" produzida pela morte dentro da sociedade e que resgata a relação do grupo com seu passado. Em segundo lugar, se configura um canibalismo produtor do movimento da "máquina social" na direção do futuro, determinando a espiral da vingança, que produz o homem cultural (pessoa completa, não "crua"). Por fim, o canibalismo assume uma função funerária: os inimigos canibais tornam-se 0 instrumento privilegiado para a transformação do morto em "bom morto".

No interior destas funções culturais, o canibalismo tupinambá caraterizase como um autêntico rito sacrificial. Se o executor, assim como a vítima, entra no "estado liminal" (está momentaneamente sem nome, morto, na espera da renomeação ritual), a sociedade está, por mérito dele, em pleno funcionamento (Viveiros de Castro, 1986: 694) ${ }^{31}$.

Se o executor do sacrifício é aquele que sustenta o processo da "reprodução" da sociedade (: 695), do ponto de vista histórico-religioso é difícil aceitar a simples constatação de que a "liminalidade" do executor e a morte da vítima colocam ambos os protagonistas (simplesmente) fora da sociedade ${ }^{32}$.

D o ponto de vista histórico-religioso, este momento da "reprodução da sociedade" só pode se dar num espaço e num tempo ritualmente determinados. Por outro lado, em relação a esta ligação do executor do sacrifício com a condição de "liminalidade", assim como com a morte da vítima ${ }^{33}$, torna-se interessante a análise do ritual do sacrifício tupinambá proposta por Fernandes.

O autor ressalta como, "após o sacrifício de sua primeira vítima, 0 jovem devia observar um complexo conjunto de ritos" (Fernandes, 1970: 201) que iam desde aqueles destinados a resguardar tanto 0 sacrificante quanto a comunidade das possíveis represálias do espírito da vítima, até os destinados à atribuição de um novo nome ao sacrificante. Estando o jovem, depois desses ritos, em condições de se casar, sucessivamente se abria espaço para as cerimônias de casamento.

D eterminados por suas funções de expressar o reconhecimento da maturidade social dos indivíduos e de promover sua integração ao círculo 
social dos adultos, tais ritos se configuram pela função característica dos ritos de passagem.

Estes últimos estruturam a atuação social (produzem, ou melhor, reproduzem a sociedade tradicional), que, no caso tupinambá é assim sintetizada por Fernandes:

o casamento, que tanto podia implicar a agregação temporária em outro grupo doméstico (matrilocalidade transitória), quanto ser realizado segundo as regras da patrilocalidade (quando as mulheres eram obtidas por meio de compensações entre parentelas); a admissão à categoria social dos "avá" , que ocorria de forma pública (através de uma cerimônia incorporada aos rituais de casamento) e que era expressa simbolicamente por meio das incisões que indicavam a aquisição do "nome"; a participação das atividades guerreiras, na qualidade de combatente, ede outras atividades sagradas geralmente acessíveis aos adultos de sexo masculino, como as reuniões dos homens para a consagração dos maracás ou para a deliberação da guerra; a faculdade de comportar-se como "avá", regulamentada pelo código ético tribal, a qual se refletia nitidamente no tratamento que deviam dispensar e receber no convívio social. 0 acesso aos demais papéis, como o de "marido polígino", os de "principal" - "chefe" de maloca, de grupo local, de bando guerreiro ou "líder guerreiro" - e os de "pajé", que eventualmente também podiam abranger os de "principal" , era conquistado lentamente, por meio da evidência de qualidades pessoais. (Fernandes, 1970: 203)

E se é notório o fato de que tanto o sacrificante, como provavelmente também as demais pessoas que adquiriam "nomes" - passando pelos ritos de purificaçã ${ }^{34}$ - não ingeriam carne da vítima, torna-se evidente 0 fato de que "o carisma não se transferia da pessoa do sacrificado para a do sacrificante, mas provinha das relações estabelecidas com os espíritos 'vingados' ou 'obedecidos'”. Por conseqüência, "o sacrificante se transformava socialmente em um 'travesti' dos espíritos ou divindades tribais" (: 211).

Enfim, as "proteínas simbólicas" que eram trocadas não estavam simplesmente contidas nas carnes do inimigo/ vítima, mas emanavam propriamente do ritual sacrificial, no qual a vítima ${ }^{35}$ representava 0 instrumento de abertura privilegiado para interagir, ritualmente, com a 
Revista de Antropologia, São Paulo, USP, 2002, v. 45 noํ 1.

realidade extra-humana a fim de reforçar e atuar em favor de uma dimensão cultural que somente pode fundar a ação histórica de uma cultura tradicional.

Em relação às características evidenciadas por Fernandes - que fazem do sacrifício tupinambá um "ritual de passagem" -, vale a pena lembrar, de acordo com Brelich, que se o segundo nascimento (as transformações das iniciações rituais) cria o homem cultural, este último representa 0 único, verdadeiro homem que uma cultura pode reconhecer. Esse fato implica a "morte" do iniciando qual ele era antes da sua iniciação. E se, em conseqüência disso,

morte e nascimento "rituais" não significam uma substituição alegórica da morte e do nascimento reais, o nascimento e a morte fisiológicas não têm, para as sociedades primitivas, uma própria realidade completa até que não sejam ritualizadas, porque os fatos puramente naturais não são unanimamente significativos. A morte do iniciando deve ser completa, eé o rito quea realiza; ea mesma coisa acontece com o nascimento do iniciado: a realidade fisiológica que está na base - isto é, que é sempre a mesma pessoa que sofre a morte e o nascimento iniciáticos - é negada pelo rito, como aparecerá, além do mais, também nos casos em que o indivíduo assumirá um novo nome, pois será outra pessoa. (Brelich, 1969: 33)

O estatuto diferencial e liminar, tanto do executor quanto da vítima, permite 0 funcionamento da sociedade realizando uma mediação que se apresenta logicamente articulada e que está na base do ordenamento cultural indígena. A "boa morte" será então constituída por uma morte mediada culturalmente, "digerida" através da captura em guerra e do cozimento sacrificial. Essa morte será tanto mais significativa se a vítima tiver contribuído, por sua vez, para alimentar o mecanismo da vingança. A morte "natural" de quem não tenha provocado a matança de pelo menos um inimigo representa a ameaça constante - tanto para o indivíduo quanto para o grupo - da ausência de um termo mediador (a cultura) e da impossibilidade de exercer um controle cultural sobre uma morte que será, por isso, "ruim". 


\section{A antropofagia e a troca dos mortos}

Segundo a análise proposta por Fernandes, a guerra intervinha na integração da estrutura social sendo o "instrumento por excelência da dominação gerontocrática e xamanística", definindo tarefas e funções de xamãs e velhos chefes. "Pelo menos uma esfera da sociedade tupinambá, a que abrangia todos os homens, era constituída e parcialmente conduzida por guerreiros, pois cabia a personalidades extraídas entre eles liderar socialmente as atividades rotineiras masculinas" (Fernandes, 1970: 227).

O ra, assim como a guerra, a utilização das vítimas se configurava como uma técnica do sistema religioso tribal. Por outro lado, não podemos deixar de levar em consideração o fato de que estas instituições eram subordinadas ao sacrifício humano. E isso, por meio de dois aspectos: "a) enquanto condição do sistema tribal de posições sociais, graças às vinculações de sacrifício humano com os mecanismos tribais de determinação do status e papéis; b) enquanto fator do equilíbrio social, em virtude da função social que desempenhava" (Fernandes, 1970: 269).

A circulação das vítimas era uma espécie de sistema de ajustamento das parentelas. A troca dos mortos criava o sistema da mobilidade das vítimas, cuja circulação era garantida pelas obrigações e direitos recíprocos existentes dentro do grupo doméstico ou entre grupos locais distintos, mas solidários. Os dados dos cronistas, sintetizados por Fernandes, chegam a evidenciar que

as trocas de escravos [as vítimas] se processavam:

a) entre "irmãos" presumivelmente, irmãos reais e classificatórios;

b) entre pessoas ligadas umas às outras como os filhos do irmão com seus pais classificatórios;

c) entre "amigos" (ou seja, entre pessoas pertencentes a parentelas solidárias e, provavelmente, ligadas por afinidade). Além disso, o marido da irmã se obrigava a presentear o irmão da mulher com seus prisioneiros de guerra; $\mathrm{e}$ 0 pai real podia presentear o filho com seus prisioneiros, visando antecipar as cerimônias de sacrifício da primeira vítima. (Fernandes, 1970: 270)

Como podemos constatar, o sistema de reciprocidade transforma 0 processo de "presenteamento" em um sistema de troca e circulação das 
Revista de Antropologia, São Paulo, USP, 2002, v. 45 no 1.

vítimas, cujo objetivo era a constituição de um mecanismo de alianças entre os agentes da troca.

Alimentos prezados, pelos valores que representam concretamente no plano simbólico, e que alimentam a competição (feroz, por si mesma, além da auto-representação Tupi da ferocidade) na contra-oferta desses alimentos: isto é quanto se tomam os prisioneiros Tupi. 0 sistema de sua troca, entre os Tupi, desenvolve-se ao redor de (e fundamenta) um valor de ligação que funda, caracteriza e sustenta as sociedades de linhagens na obrigação da dádiva: alimentando a ligação através da transformação de seus protagonistas (a "criação" do inimigo, a fim de abatê-lo antes que se torne um parente).

O prisioneiro tupi, constituído como alimento, torna-se uma dádiva e, por conseqüência, uma linguagem do implícito e do não dito. Tanto para os Tupi, quanto para os cronistas que deles falam, a antropofagia é uma simples questão de vingança, mas que, mesmo assim, obriga à restituição de uma dádiva que nunca é gratuita. São verdadeiras flechas envenenadas - paralelas ao gift de Mauss - esses prisioneiros tupi, trocados numa guerra feroz, antes de mais nada simbólica, fundamento daquela real.

A esse respeito, torna-se difícil aceitar a definição de "sociedade primitiva" proposta pela visão igualitária/ anarquista de um antropólogo que, nos anos 70, escreve que

na sociedade primitiva, sociedade essencialmente igualitária, os homens são senhores de sua atividade, senhores da circulação dos produtos dessa atividade: eles só agem em interesse próprio, mesmo se a lei de troca dos bens mediatiza a relação direta do homem com o seu produto. Tudo se desarruma, por conseguinte, quando a atividade de produção se afasta do seu objetivo inicial, quando, em vez de produzir apenas para si mesmo, o homem primitivo produz também para os outros, sem troca esem reciproddade. (Clastres, 1990: 138)

Aparece, desde já, um equívoco, uma imposição ideológica, extremamente evidente, na breve citação desse antropólogo: a troca dos bens não mediatiza a relação do homem com o seu produto (interpretação 
que se presta, evidentemente, para uma análise marxista do sistema de produção), mas, como acreditamos ter até aqui deixado claro, o bem da troca representa um instrumento, um termo mediador da relação homem/ divindades (instituído pelo sistema do sacrifício), do homem dentro de seu sistema tribal (construção de hierarquias e ajustamento das parentelas), e do homem para fora do seu sistema tribal (constituindose como mecanismo de diferenciação/ aliança).

Entretanto, é bom evidenciar que, antes de Clastres, é no domínio do político que o assim chamado "primitivismo da idade clássica" chega às suas posições mais radicais. Se nesta época as sociedades indígenas não podem ser apresentadas senão como um paradoxo aos olhos dos europeus, são principalmente as instituições políticas que sintetizam tal paradoxo. Podemos verificar esse fato, acompanhando as transformações da imagem do selvagem - que na segunda metade do século XVIII é vestido dos ideais e valores da Revolução e investido de novas bases para uma nova moralidade política - , em concomitância com o paralelo processo de assimilação dos gregos: nesta perspectiva, entre os primeiros observadores, algumas figuras (características) de chefes começavam a trazer material para as análises que Pierre Clastres realizará posteriormente.

O selvagem, caracterizado por sua eloqüência e por sua retórica instrumentos que 0 chefe indígena deve possuir a fim de exercer a própria função - , é precisamente o ponto de partida de onde Pierre Clastres começa a tecer sua própria análise/ teoria. Segundo ele, a sociedade "primitiva" não designa o lugar do poder a não ser para excluí-lo da própria realidade. Se ela atribui a um dos seus membros, simbolicamente, uma posição privilegiada, lá onde estruturalmente se correria o risco do surgimento do poder, é porque ninguém, de fato, pode ter acesso a ele. 0 poder do chefe torna-se simplesmente 0 simulacro daquilo que esta sociedade rejeita e, ao pôr esse simulacro na frente de todos, ela rejeita a sua possibilidade efetiva.

É a constituição de uma "éloquenœ naturelle" 36 que tornava o "selvagem" clássico um orador e, ao mesmo tempo, sua sociedade a realização 
Revista de Antropologia, São Paulo, USP, 2002, v. 45 no 1.

de um perpétuo debate do qual todos participam como iguais. Contudo, fora desse esquema rígido e redutivo ${ }^{37}$, se, efetivamente, 0 prisioneiro tupi transformado em alimento se torna uma dádiva, o fato de tratarse de uma linguagem implícita não impede que a palavra adquira uma significação relevante e, também, que se configure, por sua vez, como um dom.

Se, por conseqüência, na síntese do percurso histórico de uma conceituação das sociedades indígenas, inseridas numa ideologia própria da Europa do século XVIII, são criados os elementos que serão aqueles próprios da antropologia militante de Pierre Clastres, isto se torna possível na medida em que não se leva em consideração o fato de que, em vez de uma "sociedade contra o Estado", trata-se de uma sociedade caracterizada por uma ausência da "conquista cultural" que foi a do Estado por parte do O cidente (Sabbatucci, 1975). Levando em consideração esse importante fato, a palavra (como o dom) adquire, de imediato, todo seu significado de "fato social total" 38 .

Esta nova contextualização da palavra ilumina algumas situações precedentemente apontadas. D oa-se a palavra ao prisioneiro antes dele ser morto. Em seu discurso ritual - como, por exemplo, naquele relatado por Montaigne ${ }^{39}$ - , com 0 "dom da palavra" que lhe é concedido, ele pode apontar para o implícito, delineando as características de ligação que se desdobram para além do sistema da vingança. Por outro lado, esse "dom da palavra" define outro processo (que gostaríamos de definir, provisoriamente), de areté ${ }^{40}$ cultural Tupi, mas que, melhor, precisaria encontrar sua própria expressão lingǘstico-cultural, mais próxima, talvez, ao ñande rek o ("nosso modo de ser") guarani, estudado por Meliá (1981: 1-24).

Paralelamente e para além da guerra, trata-se do sistema que se refere à função cultural específica do caraíba. Ele

se subtrai programaticamente às regras do viver social, caracterizando com 0 excesso ou com o defeito as próprias relações em nível linguístioo (é silencioso/ exprime-se com voz de criança, canta), social (é solitário/ é, às vezes, polígamo) 
e alimentar (não produz, não consome/ recebe bens em excesso). A negação das regras da troca o põe num plano "outro" daquele da comunidade social, e é de fato fora dela que ele vive. (Pompa, 1981: 62) (1 $^{41}$

Excesso ou defeito, em relação ao cotidiano, nos seus estatutos (peculiares) lingüístico, social e alimentar, o caraíba, com seu "dom da palavra" e com sua "vocação itinerante", se constitui, ele mesmo, quase como verdadeiro kula físico que assume e distribui valor cultural através de sua circulação, tornando significativas as relações sociais Tupi. Em conseqüência disso, e levando em consideração a palavra como fato social total, ele não poderá assumir, de forma alguma, aquela conotação política, extremamente restrita e (funcionalmente) eurocêntrica, delineada por Clastres.

$$
* * * *
$$

As informações que chegaram até nós a respeito da prática propriamente alimentar, dentro do ritual sacrificial tupi, são muito escassas. Mesmo assim, se a função das escolhas e dos comportamentos alimentares, nos sistemas sociais humanos, visam à homogeneização interna da cultura e, em conseqüência, à separação do externo, estes dois processos nunca se constituem por si só. $\mathrm{O}$ ex terno contribui substancialmente para a construção do interno, com todas suas proteínas simbólicas ${ }^{42}$.

Ao que tudo indica, tanto a linguagem quanto a alimentação assumem seu significado mais profundo devido à sua função necessariamente mediadora. O ra, se na nossa sociedade esta complexa relação interno/ externo serve à determinação do que se constitui, historicamente ${ }^{43}$, como "civilização", na cultura Tupinambá este fato determina e funda, ao mesmo tempo, as características que fazem de um Tupi um "bom" Tupi $^{44}$, em sentido propriamente antropológico (antropofágico?), "apetecível" pela sua capacidade de entregar-se a (e alimentar) um modelo cultural que lhe garanta o fundamento de sua identidade e o espaço de sua ação cultural. 
Revista de Antropologia, São Paulo, USP, 2002, v. 45 noํ 1.

Vale a pena pensar, nesse ponto, quanto se destaca de um instigante estudo de Sabbatucci que, em sua análise, evidencia as diferentes e correlatas caracterizações de: "o mito por si, enquanto genesis; 0 mito em relação/ oposição à história, por sua capacidade de fundar uma realidade metahistórica; 0 mito em relação-oposição à cultura, por sua capacidade de fundar uma realidade natural"; por outro lado, deve ser destacado quanto esse instrumento cultural pode se abrir "à relação/ oposição técnica que ele tem com o rito" (Sabbatucci, 1978: 79). Na perspectiva apontada pelo autor, obteríamos um duplo resultado: um, teórico-fenomenológico, e outro, prático-historiográfico.

Transcrevendo as palavras de Sabbatucci, destacar-se-ia como

a teoria-fenomenologia seria redutível à fórmula mito: rito = imutável : mutável; o imutável sendo o não passível de intervenção (humana) e o mutável passível de intervenção. Em outros termos: em uma cultura tudo quanto é objeto de mito é incluído na área do imutável e subtraído à intervenção humana (ou seja, se quer que seja subtraído a ela), enquanto aquilo que não se quer que seja subtraído à intervenção humana torna-se objeto de rito. (: 236)

Partindo desse resultado, vale a pena pensar que, se esta relação entre mito e rito se coloca de modo diferenciado $0^{45}$, da mesma forma, nas várias culturas e nos sistemas sociais humanos, parece se constituir como um "dado" - que necessariamente tem que aparecer como imutável - a função das escolhas e dos comportamentos alimentares que visam à homogeneização interna da cultura e, em conseqüência, à separação do externo. Mas, se esses dois processos nunca se constituem por si só e se 0 externo contribui substancialmente à produção do interno ${ }^{46}$ - a cultura Tupinambá também determina e funda em suas manières de table míticas ${ }^{47}$ as características imutáveis do "bom" Tupi que lhe garantem o fundamento de sua identidade e em suas manières de table rituais - nas quais, juntamente com a cauinagem, se destaca o sacrifício humano - 0 espaço de sua ação cultural. Nesse sentido, a ritualidade da prática antropofágica configuraria os "selvagens" canibais, não como relegados ao estado de natureza ou a seu próprio desejo. O perando através do 
ritual e compelidos por seu canibalismo, os Tupi manifestam sua necessidade fundamental (real e culturalmente protéica) de viver em sociedade, continuando a alimentar a própria cultura em seus fundamentos míticos através de sua ação ritual.

$$
* * * *
$$

Se, tanto na perspectiva cultural bíblica quanto naquela grega, encontramos a centralidade da prática sacrificial humana num tempo mítico (tempo des-historificado), apesar de sua substituição no ritual (tempo histórico), a cultura Tupi desvenda a centralidade, no tempo mítico, de um jaguar em illo tempore "senhor do fogo", cedido ao homem, em troca da esposa humana.

A esse respeito, nos parece que as divergentes interpretações de LéviStrauss e Pierre Clastres, sobre a função da guerra para as sociedades tupi ${ }^{48}$, podem encontrar um ponto de convergência.

Se a reprodução simbólica da comunidade Tupi surge por causa da exigência de neutralizar a ameaça do estranho através de sua incorporação, os bens da troca (fogo e esposa humana) se caracterizam como termos de uma mediação que é, ao mesmo tempo, diferenciação e assimilação. 0 homem adquire um bem, de um jaguar, o qual ele transformará em instrumento cultural; por sua vez, o jaguar obtém um bem, do homem, que ele transformará em fera canibal: o jaguar "animaliza" a mulher, enquanto o homem "culturaliza" o fogo. D essa maneira, parece que a assimilação se constitui como uma "alteridade culturalizada", enquanto a diferenciação se apresenta como uma "alteridade animalizada". Mas o que se torna significativo, na análise do ritual sacrificial Tupi, é 0 fato de que é graças à mulher que a alteridade do inimigo/ vítima pode ser introduzida e, até um certo ponto, assimilada na vida da aldeia. Isso porque a mulher que assume tal função evidencia um vazio que fala através dela: é a voz do(s) morto(s) e de suas exigências. E se, como vimos anteriormente, "os mortos são os jaguares", a mulher serve como a mediação dessa dupla alteridade da cultura Tupi. 
Revista de Antropologia, São Paulo, USP, 2002, v. 45 no 1.

Q ualquer que seja a alternativa - a alteridade que é produzida pela, ou que produz a, guerra -, é sempre essa alteridade que se configura como essencial à reprodução da comunidade. Segundo o que outrora afirmamos, a troca das mulheres, que assegurava a reprodução social efetiva, estava estritamente associada à troca das cabeças (à troca dos mortos, no caso tupi) que, enquanto reprodução social simbólica é, na perspectiva das atividades rituais, igualmente efetiva.

O ra, é pelo menos curioso observar um paralelo grego evidenciado por Hartog, que observa : "Para os gregos, existe uma polaridade, isto é, uma disjunção e ao mesmo tempo uma complementariedade entre a guerra e o casamento: uma é aquilo que cabe aos homens; o outro aquilo que cabe às mulheres; a guerra e 0 casamento marcam respectivamente a união do jovem homem e da jovem mulher" (1980: 229) ${ }^{49}$.

Torna-se assim evidente um paralelismo que, se no caso dos gregos e, em parte, dos citas (analisados por Hartog), destaca uma correlação entre função de matar (dos guerreiros) e função reprodutiva (das mulheres), por outro lado ecoa o paralelo e a correlação analisada na sociedade Tupi como uma "troca dos mortos" correlativa a uma "troca das esposas". A respeito dessa sociedade, devemos observar que, tanto nas obras de Fernandes, quanto no artigo "Vingança e temporalidade", de Carneiro da Cunha e Viveiros de Castro, existe, de fato, um acordo comum em relação à análise e interpretação dos testemunhos - sobre a relação entre 0 feito guerreiro - que, enquanto fonte de prestígio político, permite por decorrência a existência da poligamia - e a aquisição de mulheres.

E se trata-se de uma correlação entre função homicida e função reprodutiva que, segundo Lévi-Strauss, torna manifesta uma exigência própria do "pensamento mítico", por outro lado, essa é uma correlação que determina (e é determinada profundamente e ao mesmo tempo por) um processo ritual que não é mera recriação daquele pensamento mítico.

$\mathrm{N} 0$ mito, de fato, ao jaguar, caçador que não pode ser caçado, se substitui o homem (caçador e caça ao mesmo tempo), obtendo em troca o fogo, que unicamente pode dar fundamento à instituição do sacrifício 
(ritual), através de uma mulher (a caça que não pode caçar), enquanto instrumento de dádiva e troca que garante a reprodução social.

$\mathrm{N}$ o rito, ao invés, é posto em cena um prisioneiro - que representa a caça que (antes) era também caçador - e um capturador - caçador, mas que pode (sucessivamente) tornar-se, também, caça - que compartilham e asseguram, através da mulher, uma reprodução social efetiva e, por meio do rito (sacrificial), uma reprodução social simbólica, porém não menos efetiva.

À alteridade não-humana do mito (o jaguar), à qual deve ser subtraído o bem necessário para fundar, num tempo des-historificado, a cultura realmente humana (o fogo sacrificial), é substituída, no rito, a alteridade humana ${ }^{50}$, com a qual se pode e se deve (mas só ritualmente) interagir a fim de alimentar o processo cultural no tempo histórico.

A hierarquia, que se inscreve ao longo desse percurso, determina, também, a constituição de uma hierarquia interna que - fundada pelo sacrifício ritual na sua específica forma de dividir as carnes (seu simbolismo) do corpo da vítima em relação ao corpus social, conforme o modelo grego - decalca também, a fim de uma discriminação culturalmente significativa, a relação do percurso interno/ externo, fundando e definindo, ao mesmo tempo, os diferentes níveis sociais internos, "organizados" hierarquicamente. De fato, a organização (nunca estática) é forma cultu(r)al e se dá numa dimensão em que a cultura desvenda sua ligação - não só semântica - com o culto, isto é, uma alimentação dos deuses que sustenta a ordem cultural (cósmica) ${ }^{51}$.

Se, portanto, a mesa se configura como "une machine sodiale, compliquée, efficace" (Giard, 1996: 278), o rito sacrificial também significa, diz, produz, como qualquer rito, uma ordem (humana) do mundo. É a ação sacrificial (ritual) que postula (deve postular) a inscrição de tal ordem como conseqüência desta ação, tornando assim o ritual (sacrificial) 0 momento de fundação da comunidade.

No caso tupi, pode-se falar de solidariedade social alimentada por um sistema de cooperação competitiva das parentelas nas atividades guerreiras e cerimonias. E se o aprisionamento de "escravos" 
Revista de Antropologia, São Paulo, USP, 2002, v. 45 noํ 1.

constituía um produto da guerra, à medida que o modo de apropriação de escravos encontrava nas atividades guemeiras a sua fonte material ea sua origem imediata [...], reciprocamente ela [a escravidão] se tornava uma condição permanente da guerra. Em segundo lugar [...] os rituais de aprisionamento ede integração à comunidade dos captores não determinavam o fim do estado de guerra, mas a sua continuação sob outra forma. Era como inimigo que 0 escravo realizava o seu destino devítima e o fazia, dentro de suas possibilidades, de modo agonístico, vivendo o sacrifício como uma situação de luta à mão armada. (Fernandes, 1970: 271-72)

Para entendermos plenamente este processo cultural Tupi, temos que lê-lo e interpretá-lo conforme a perspectiva histórico-religiosa que, significativamente, constitui a abordagem de nosso estudo. Pela pesquisa de um historiador ou de um antropólogo, a realidade não tem, e não pode ter, por objeto exclusivo a qualidade dos poderes (em referência ao "mundo mágico" de De Martino) ou das práticas (por exemplo, a antropofagia) - que por si mesmos, freqüentemente, já transformamos em categorias do real - , mas deve, antes de mais nada, ter como "objeto" de análise o nosso próprio conceito de realidade, no qual o sujeito de juízo e o conceito de realidade se encontram envolvidos.

E este último tipo de análise será possível apenas quando ${ }^{52}$ conseguirmos tornar os dados um problema, a fim de "superar radicalmente as instâncias polêmicas que limitam o nosso horizonte historiográfico e que nos impedem de 'compreender' o mundo mágico" (De Martino, 1986: 248-49).

D essa maneira conseguiremos entender que, se a morte não representa outra coisa a não ser a linha de demarcação social que separa os vivos dos mortos ${ }^{53}$, mesmo na sua diferença - ou melhor, justamente por causa dela -, os mortos podem permanecer partners dos vivos em numerosas formas de trocas. E se "a morte subtraída à vida é a própria operação do econômico - é a vida residual, doravante legível em termos operacionais de cálculo e valor. A vida entregue à morte - essa é a operação do simbólico" (Baudrillard, 1996: 177).

Num mundo envolto no drama de uma presença continuamente exposta ao risco de não ser (estar) no lugar (esserci $)^{54}$, que age através de 
seus instrumentos mítico-rituais para se defender desse risco, enfim, em um mundo definido como "selvagem", o "conceito" de morte assim como o de nascimento, doença etc. - não é um conceito biológico. De fato, nesse espaço a morte se configura como

contexto de uma troca recíproca/ antagônica entre os ancestrais e os vivos e, em lugar de uma separação, instaura-se uma relação social entre os parceiros, uma circulação de dádivas e de contradádivas tão intensa quanto a circulação de bens preciosos e de mulheres - jogo incessante de respostas em quea morte já não pode instalar-se como fim ou como instância. Pormeio do alimento, 0 morto é incluído na vida do grupo. Mas a troca é recíproca. $\mathrm{O}$ morto dá sua mulher, a terra do clã, a um vivo de sua família, a fim de reviver ao assimilarse a ele e de fazê-lo reviver assimilando-0 a si. (Baudrillard, 1996: 180)

\section{Notas}

1 Trabalho extraído de nossa tese de doutorado, intitulada 0 apetite da A ntropologia: o sabor antropofágioo do saber antropológio. A lteridadee identidadena cultura T upinambá (1998).

2 L aurea em Filosofia junto à Universidade de Pádua. Pesquisador em História das Religiões da mesma universidade. D outor em Sociologiajunto à Universidade de São Paulo. D esenvolvendo, atualmente, um projeto de pós-doutorado junto ao D epartamento de História da Universidade de São Paulo.

3 Para uma rápida revisão dessa produção, com particular atenção ao período iluminista, veja-se 0 artigo de Rousseau (1995: 607-51).

4 Assim, por exemplo, em Viveiros de Castro (1986: 56-78), no artigo "Vingança e temporalidade: os tupinambá", escrito em colaboração com Carneiro daCunha e na obra A raweté. Com essa metodologia de análise, que tem na comparação um de seus instrumentos privilegiados de indagação/ verificação de certas realidades culturais, começamos por detectar os limites da comparação que são próprios do trabalho de Viveiros de Castro, em outros aspectos um interessante e estimulante compêndio bibliográfico e etnográfico. Esta comparação - segundo nós superficial - com o mundo grego, e com seus estudos críticos ligados 
principalmente à escola francesa (melhor, quase exclusivamente ao trabalho de D etienne), faz que ele veja a cosmologia tupi-guarani propender na direção da constituição de anti-sistemas, como o dos gregos. Isso, quando ele não afirma simplesmente o óbvio, no momento em que "descobre" que essa cosmologia tupi coloca a condição humana não só como intermediária entre a animalidade e as divindades mas, como fundamentalmente precária, um momento que deve ser superado. Por conseqüência, o espaço da cultura se constituiria como um ponto de passagem, lugar equívoco e ambivalente. A conclusão desse autor é um tanto problemática, na medida em que se constitui num plano filosófico (grego) e não num plano propriamente histórico (tupi). É dessa forma que, sem devidamente problematizar certas categorias (instrumentos da análise), como, por exemplo, a de religião, de profetismo, ou a ritualidade das práticas antropofágicas que se referem à cultura tupi-guarani, ele chega a afirmar que, mesmo conhecendo pouco sobre a religião tupinambá, o profetismo e 0 canibalismo parecem configurar-se como uma síntese da procura da superação da condição humana, "em direção de cima" ou "em direção de baixo".

5 A esse propósito, desvendam-se os limites da procura dos paralelos gregos, que parecem revelar, ao referido autor, o "paradoxo" da religião tupinambá que se configuraria como uma "ortodoxia dionisíaca" (Viveiros de Castro, 1986: 627). Tal definição não tem algum sentido referindo-se a uma religião. Eis que 0 autor destaca, conseqüentemente, uma antropofagia apresentada como uma negação da sociedade - e a esse respeito torna-se evidente a influência de Hélène e de Pierre Clastres - ao mesmo tempo em que representa o seu principal rito políticoreligioso. D estacar-se-ia, dessa forma, uma sociedade tupinambá, que, em face de um $O$ cidente que ex dui as povoações marginais - relegando-as a uma dimensão "barbárica", selvagem e canibalesca - , indui os próprios inimigos, tratando-se, portanto, de uma sociedade que não existe fora da relação com o "outro": uma sociedade que necessita dos mortos alheios e da morte em mãos de outrem. Encontra-se, assim, um regime social fundado na "troca dos mortos", em vez de na "troca das esposas". A execução ritual do inimigo fundava, então, a sempre lábil unidade da aldeia. Até aqui, em síntese, a indicação de alguns pontos obscuros e, parafraseando o texto, muitas vezes paradoxais do trabalho de nosso autor.

60 relato de Hans Staden (Viveiros de Castro, 1986: 621) constitui-se como base da análise que será desenvolvida por Viveiros de Castro em seu trabalho no cap. VII (: 623-700). 
7 Relevamos, de passagem, que a resposta tupi "Jauáraichê" significa simplesmente uma identidade, traduzindo literalmente "eu (sou) jaguar", constituindo-se, evidentemente, como um complemento à segunda parte da tradução do viajante.

80 "vocabulário do canibalismo grego" é pedido em empréstimo a D etienne (1987: 235).

9 Mas é esse ponto que não conseguimos entender: em que medida tudo isso se configura como um "questionamento da Cultura" e o que explica (se é que pode "explicar" algo!) a constatação de que, neste fenômeno eminentemente cultural, trata-se de uma colocação em discussão da cultura, de uma sua problematização, de uma maneira "de transcendêla 'por baixo': pela natureza" (Viveiros de Castro, 1986: 627).

10 Sublinhamos, sem querer sermos exaustivos - nem nesse ponto -, alguns exemplos significativos tirados de duas obras nas quais é dedicado grande espaço a essa análise. Em Lévi-Strauss (1991): encontramos o jaguar como origem do fogo (: 96-106, 108-10); jaguar e homem como termos polares (: 117-20); troca da esposa (humana) pelo fogo (do jaguar) (: 129); jaguar como manifestação da natureza versus cultura (: 132-33); origem do jaguar (mito M22: 138); relação tabaco/ jaguar (: 138-40, 146-47); comunicação das artes da civilização (: 150); relação com o rir (: 164-79); cru/ cozido, cru/ pútrido como relação natureza/ cultura (:190-91, 231-35); vida breve como função da origem do fogo de cozinha (criador) (:246-55); aspecto alimentare sexual (:350-51); alimentação, canibalismo e fogo (: 377-78, 388 e ss., 410-11). Em Lévi-Strauss (1967b): encontramos 0 jaguar como senhor do fogo (:17-30, 35-47) - veja-se também, a respeito dessa temática, a síntese de L e cru et le cuit - ; cru/ fermentado, em relação a pútrido/ cozido; jaguar canibal (: 274 e ss.); jaguar e esposa humana que torna-se fera canibal (:35-6).

11 Pois é um carnívoro que não mata para comer (carne), portanto é caracterizado pela atitude própria dos herbívoros, mas se alimenta de carniça (carne-vítima morta por outros) (Lévi-Strauss, 1967a: 259-60).

12 Conferir a análise, das noções de comestibilidade e das relações com animais domésticos, desencadeada por Barthes (1982 e 1961); Leach (1964); D ouglas (1976); Sahlins (1976); Valeri (1977); Bonnassie(1989). 
13 Ele mesmo declara a inspiração em Lévi-Strauss, em particular a obra D u miel aux cendres.

14 Grifo nosso. Note-se de passagem que o termo "frechadas" é do próprio Sérgio Buarque de Hollanda.

15 "Que atrai os seres", assim chamado estado de bayja.

16 É interessante que, sucessivamente, o mesmo Clastres afirma o que tínhamos acima afirmado, isto é, em relação a esse exemplo, ele diz que "o ritual é o meio de transformar, socializando-0, um dado bruto imediato em um sistema simbólico mediatizado; ou, para dizêlo de outro modo, é no e pelo espaço do ritual que a ordem natural se converte em ordem cultural" (1995: 24). 0 fato de que matar um jaguar não representa a matança de qualquer caça - e que, portanto, assume as características próprias do ritual - é representado pelo fato de que o caçador (do jaguar) "é friccionado também com uma grossa concha de caracol, para que não encontre outros jaguares, desejosos de vingar seu congênere" (: 183).

17 Longe de representar um "questionamento da Cultura", que seria uma maneira "de transcendê-la 'por baixo"' (pela natureza), como quereria Viveiros de Castro.

18 Que, longe de ser completa, neste breve esboço proposto, só quer ressaltar algumas características para uma colocação do problema.

19 Pela qual era suficiente que o capturador batesse sua mão nos seus ombros para vê-lo submisso, seguindo-o e servindo-o em toda fidelidade.

20 Mesmo que por razões nobres e generosas, em relação à sua época.

21 Publicadas, respectivamente, em 1948 e 1952.

22 Mais do que nas categorias ocidentais "coragem", "nobreza" ou "generosidade", que levam para a concepção estética de "beleza", proposta por Montaigne.

23 Por conseguinte, "enquanto que os ritos funerários tinham por objeto assegurar a integridade do ser [...], os ritos antropofágicos visavam expressamente 0 
contrário. As ações canibalísticas pertenciam a uma categoria especial de manipulações, que dava aos agentes vivos a possibilidade de aplicar em benefício próprio as alterações da integridade do ser na pessoa da vítima" (Fernandes, 1970: 30). E, mais adiante, "a conexão do sacrifício humano como ritual funerário resulta da própria função mágico-religiosa que os ritos de 'destruição' do inimigo possuíam quando consagrados ao 'espírito' de um parente morto recentemente. O sacrifício sangrento de uma vítima removia o agente de perturbação, que impedia o estabelecimento de relações normais entre o morto e a coletividade", em conseqüência, a restauração deste equilíbrio se dava "por meio da exclusão do morto do círculo social dos vivos e de sua concomitanteintegração à sociedade dos ancestrais míticos e dos antepassados" (: 333).

24 É interessante observar como o sacrifício adquire a possibilidade de representar e sintetizar (ou seja, de produzir) todo o processo cultural. Isto é confirmado pelo fato que "graças às relações e às obrigações de parentesco, alguns jovens não se submetiam às provas 'militares'; limitavam-se a sacrificar um inimigo, recebido de 'presente' do seu pai, ou do marido da irmã, e a passar pelos ritos subseqüentes de renomação" (Fernandes, 1970: 149-50).

25 Não se trataria, então, da alternativa de uma sociedade fundada na "troca dos mortos", em vez de na "troca das esposas", como quereria Viveiros de Castro.

26 Assim, se para dois termos (como por exemplo "vida" e "morte") não é possível estabelecer uma correlação, porque impossível parece a "passagem" conceitual, podemos substituir os termos polares com dois outros equivalentes (a "agricultura" ea "guerra" ) que admitam um intermediário comum (a "caça") (LéviStrauss, 1967a: 259-60). Eis que na mitologia dos povos norte-americanos "a 'filosofia' da caça às cabeças sugere uma afinidade entre os troféus e o sexo feminino. Os escalpos passavam de imediato às mãos das mulheres, ou dos homens aparentados através das mulheres com o conquistador do troféu" (1968: 328-29). Ainda, "o pensamento mítico assimila a caça às cabeças à caça às mulheres (entre os índios das planícies, a guerra servia tanto para um como para outro objetivo)" (1967a: 330). Por este caminho o escalpeador chega a estabelecer uma equivalência entre guerra e matrimônio que corresponde de forma plena à estabelecida pela cultura Tupinambá.

27 D e fato, como sublinha Lévi-Strauss, os mitos acerca da origem do fogo tanto entre os Gê quanto entre os Tupi-Guarani “operam por meio de uma dupla 
oposição: entre cru e cozido por um lado, entre fresco ecorrompido por outro. 0 eixo que une o cru e o cozido é característico da cultura, aquele que une o cru e o pútrido 0 é da natureza, isto porque o cozimento atua a transformação cultural do cru, como a putrefação é a sua transformação natural". Partindo desses pressupostos, o autor conclui que "o limite entre natureza e cultura encontra-se contudo deslocado, dependendo se nós considerarmos os gê ou os tupi. Para os primeiros ele passa entre 0 cru e o cozido; para os segundos entre 0 cru e 0 pútrido. Os gê fazem portanto do conjunto (cru + pútrido) uma categoria natural; os tupi fazem do conjunto (cru + cozido) uma categoria cultural" (LéviStrauss, 1991).

28 Veja-se, a esse respeito, todo o processo ritual de "conversão do cativo em vítima [e como] promovia a suaintegração à comunidade dos captores" (Fernandes, 1970: 276-91): torna-se evidente, assim, como se através deste processo atuasse um atento controle ritual.

29 "Em torno das obrigações dos vivos para com os mortos, da vingança dos antepassados, e da satisfação dos desejos antropofágicos dos espíritos, é que se polarizavam as vivências masculinas e os núcleos de condensação e de intensificação da vida social, especialmente dos homens. A conquista do novo nome, que condicionava socialmente a transformação da personalidade masculina, segundo as concepções tribais, eque daria lugar à 'promoção' para o status de homem, através dos rituais de sacrifício do inimigo e de renomação, se processava graças às relações que se estabeleciam entre o matador e 0 espírito do ancestral ou do parente morto de modo sangrento, vingado publicamente" (Fernandes, 1970: 153). Por outro lado, "após os rituais de execução, quando o matador ia entrando em sua maloca, os companheiros arremessavam-se aos objetos de seu uso pessoal [citando $\mathrm{G}$ abriel Soares, Cardim e Thevet]. Se tinha 'alguma coisa boa, quem primeiro anda lha toma até ficar sem nada' [Cardim]. Ele, por sua vez, nada devia fazer, deixando que levassem 'tudo sem falar palavra' [G abriel Soares]. As ligações destes comportamentos com ritos de morte e de renascimento são evidentes, pois mais tarde o matador adquiria um novo nome e outra personalidade. 0 outro exemplo é relatado por Thevet, e tem grande valor, porque nos informa sobre a única situação em que os objetos pertencentes a um morto podiam ser alienados de sua pessoa. No outro caso, assim que os tupinambá entravam no grupo local, conduzindo um prisioneiro, levavam-no àmaloca do defunto cuja sepultura devia ser renovada. Diante do escravo punham o arco, as flechas, a rede, etc., objetos que tinham pertencido em vida ao defunto. Ele devia servir-se destes objetos 
enquanto vivesse" (1989: 127-28). E, mais para a frente, o autor, descartando a hipótese que o matador adquirisse novas qualidades ou "poderes vitais" da vítima, pelo simples fato que lheéexpressamente proibida aparticipação no repasto coletivo, indica "ter encontrado essa fonte nas relações estabelecidas pelo matador com os seus antepassados, na fase mais crítica dos ritos de renomação" (: 237).

30 O nde afirma que "a revindita abrangia três coisas distintas. Em primeiro lugar, o grupo precisava redefinir suas relações com o morto, atribuindo-lhe a posição compatível com seu novo status. Em segundo lugar, o grupo devia renovar as anomalidades acarretadas pelo desaparecimento de um membro. 0 morto devia ser substituído e o seu grupo social compensado pela perda de um membro. Em terceiro lugar, tornava-se necessário restabelecer os laços intragrupais e intratribais de compromissos recíprocos e de solidariedade social". E is aqui os elementos que Viveiros redefinirá como os três diferentes registros culturais.

31 De forma análoga, como por exemplo entre os mundurucus, caçadores de cabeças da Amazônia central, o guerreiro que tinha conseguido uma cabeça, tinha o privilégio de convocar uma festa que podia demorar por três estações de chuva sucessivas. Tal festa, completamente centralizada no tratamento da cabeça, tem para nós grande importância pelas normas que, por toda a duração, regulavam a vida do caçador de cabeças e a de sua mulher. D urante todo aquele tempo eles não podiam ter relações sexuais e ele não podia, também, participar das refeições comuns, das conversas (a não ser a respeito de argumentos particularmente sérios). Além disso, participava de forma especial das empresas coletivas de caça: só presenciando (não podia caçar), junto a seu o próprio "troféu" - que servia para assegurar o sucesso da empresa - , devendo retirar-se para sua casa depois dos primeiros animais terem sido abatidos. Naquela temporada também sua esposa assumia um poder particular, podendo mandar em todas as outras mulheres e sendo preservada de qualquer trabalho (Brelich, 1966: 102-3). A respeito dessa analogia (que havíamos anteriormente relevado), recentemente lemos um trabalho que confirma nossa análise. Nele se destaca que "o estatuto da cabeça enfeitada [entre os mundurucus] lembra o do cativo tupinambá; a relação entre o matador e o troféu evoca também o par matador/ vítima entre aqueles Tupi quinhentistas. A situação do matador [...] apresenta mais um paralelo com o matador tupinambá na hora do festim final: ele é submetido a uma rigorosa abstinência sexual. Os dois outros resguardos típicos da couvade também se verificam: proibição de caçar (para o matador) e cozinhar (para sua esposa)" (Menget, 1993: 315). Observe-se, aqui de passagem, a comelação, de que já falamos, 
entre sexo, caça e cozinha. Sempre em relação à condição, culturalmente estabelecida do capturador, trata-se, com efeito, da mesma "liminalidade" e identificação entre vítima ecapturador que encontramos, por exemplo, na prática ritual-sacrificial asteca onde o banquete, com as carnes davítima, era ritualmente oferecido pelo capturador que, igualmenteneste caso, não participava da refeição canibalesca. Esse fato podia eventualmente se configurar como um verdadeiro epróprio incesto. "A identificação entre capturador e vítima é destacada porvários fatos, entre os quais: na fórmula da captura, 0 vencedor se declarava 'pai' do vencido; 0 capturador não participava da refeição canibalesca ('deveria comer a mim mesmo?', perguntava); o capturador era pranteado, como se fosse ele mesmo a dever morrer, e ornado dos paramentos próprios da vítima" (Brelich, 1966: 252-53).

32 Tal como sugere Viveiros de Castro - e isso seria feito de modo inverso do que ocorre com a ferocidade homicida que coloca, decididamente, o indivíduo dentro da cultura do grupo. D a mesma forma não tem sentido a afirmação de que "a cerimônia cria um duplo afastamento da Cultura" (1986: 696). Tanto para um antropólogo, quanto para um historiador das religiões, essa afirmação resulta sem sentido, tanto mais na medida em que é posta, contudo, como conclusão de uma bela etnografia, elaborada, porém, juntamente a uma comparação cujos limites tentamos apontar sinteticamente.

33 Q ue coloca ambos os protagonistas fora da sociedade, mas somente dentro de um mecanismo operativo mítico-ritual que tem a função de readquirir, através desta dialética com a dimensão extra-humana, a possibilidade operativa para agir na história, novamente "autenticada", isto é, recuperada à cultura humana, através dos instrumentos rituais.

34 Trata-se, além do captor (ou captores) da vítima, dos guerreiros (os sacrificadores), que subjugavam a vítima na fuga simbólica, tanto por meio da execução das vítimas, quanto por meio do esfacelamento de caveiras (Fernandes, 1970: 205).

35 Humana ou o jaguar: o único outro exemplo significativo, conhecido nessa cultura.

36 Que seria própria dos selvagens.

37 Q ue constituía o "selvagem” em sua assimilação com os gregos. 
38 E, como relevava Lévi-Strauss, "que o fato social étotal não significa apenas que tudo 0 que é observado faz parte da observação, mas também, e principalmente, que em uma ciência em que o observador é da mesma natureza que 0 seu objeto, 0 observador é, elemesmo, partedesua observação" (Lévi-Strauss, 1974: 16).

39 A saber: "Que se aproximem todos com coragem e se juntem para comê-lo; fazendo-o, comerão seus pais e seus avós, que já serviram de alimento a ele próprio e deles seu corpo se constituiu. Estes músculos, esta carne, estas veias, diz-lhes, são vossas, pobres loucos. Não reconheceis a substância dos membros de vossos antepassados que, no entanto, ainda se encontram em mim? Saboreaios atentamente, sentireis o gosto de vossa própria carne" (Montaigne, 1987: I, 265).

40 Será que podemos nos permitir o termo grego para medir o que épróprio, neste caso, do processo cultural tupi?

41 A respeito da problemática do profetismo indígena, veja-se todo o artigo da autora, às páginas 7-120.

42 A esse propósito já vimos, ao longo de nosso mais amplo estudo (Agnolin, 1998), como o gosto individual (interno) não deixa de ser reconhecido pela, e ligado à, estratificação social (externa), criando, portanto, uma homologia termo a termo entre grupos sociais (de reconhecimento) e condutas (de preferências); vimos como 0 ato de comer (tanto em sua conotação alimentar, quanto naquela sexual) diz respeito a um desejo íntimo (interno) voltado para um objeto (reconhecimento) exterior, que é quase uma "projeção da devoração" que, na assimilação do que é externo ao organismo, transforma o sujeito em relação a seu ato; vimos, sobretudo, como as duas oralidades, emissão de palavras e absorção de alimentos, estão fortemente ligadas, desvendando uma profunda analogiaentrea relação do homem com aalimentação - um extemo quetransforma o estado (interno) do indivíduo - e a sua relação com a linguagem, que impõe uma forma específica à substância de um conteúdo, a priori, indiferenciado.

43 Isto é, como processo em perpétua transformação.

44 Não num sentido moral ou, próximo desse, um sentido ocidental, que se refere à distinção entre bom e mau selvagem. 
45 Sabbatucci evidenciou esse aspecto por meio de uma análise histórica de riqueza exemplar. A diferente configuração histórica na qual é representada esta relação é colhida entre, por exemplo, a função do "Criador Supremo" africano N vidi M ukulu, dos lulua - população bantu do Kasai - e a concepção genética da Grécia antiga, ligada ao instituto mítico-ritual da regalidade [do lat. regale, que diz respeito aos reis] e passando pela grande transformação da "revolução gentílica" - a alternativa mítico-lógica (via tragédia) em face da qual se colocou a cultura ateniense; de modo que, se "a função de um mito é a de fundar uma realidade que se apresenta, ou se quer, como 'dada': o dado natural no qual, mas não sobre 0 qual, operam os homens, [por outro lado] a tragédia funda a realidade políticosocial ateniense, que, dependendo das capacidades do poeta, écolhida e representada como 'querida': a conquista cultural que os atenienses são chamados a defender, ou a reconquistar à consciência , cada vez que é problematizada" (Sabbatucci, 1978: 157).

46 D ando vida, por exemplo, ao que num determinado período da história do O cidente foi chamado de "civilização"'. Conferir, a esse respeito, a análise do processo civilizatório desenvolvida pela obra de Elias (1939).

47 Nas quais, como vimos, se destaca principalmente a figura do jaguar numa dimensão (característica dos mitos) em que ainda não é dada uma nítida divisão entre os reinos vegetal, animal e humano, enquanto é mostrada em seu definir-se.

48 Em nosso trabalho (Agnolin, 1998: 156-57) mostramos como Lévi-Strauss deduzia que comércio e casamento teriam a função de criar uma aproximação entre homens (que, de outra forma, seriam estrangeiros), ao contránio de Clastres que - partindo do pressuposto de que se trata de comunidades (tupi) que partilham uma mesma cultura e portanto precisam refundar constantemente a identidade da comunidade territorial - acredita que a guerra não nasce por causa da alteridade, mas serve a criar a alteridade.

49 "Não ou guerra ou casamento, mas guerra ecasamento" (grifo nosso); 2) e uma conjunção: "às mulheres, não se faz a guerra, se fazem procriar filhos". Nesta conjunção entre fazer a guerra e fazer amor, a guerra (matar um inimigo para levar-lhe 0 escalpo) se torna algo que (ritualmente) qualifica para o casamento (Hartog, 1980: 232).

50 Q ue é um "quase jaguar", mas não é completamente assim na medida em que pode se tornar, também, caça. 
51 Como releva Brelich, de fato, "por várias concepções religiosas \{...] são os seres sobre-humanos a exigir um culto: trata-se da forma mais perfeita da projeção da necessidade que tem o homem da existência desses mesmos seres e de ver por eles determinado o próprio comportamento. Só raramente aparece a idéia (particularmente significativa) de que 'D eus precisa dos homens', isto é, por exemplo, que os seres sobre-humanos morreriam de 'fome' sem os sacrifícios, ou, mais simplesmente, cessariam de existir, na ausência do culto. Esta idéia se afirma em certos comportamentos religiosos ('reza-ameaça', altares revirados, supressão dos cultos), portando ao nível da consciência o fato, que se quer ignorado, de que os seres sobre-humanos não existem a não ser à medida que o homem os faz existir, os sustenta, os cultiva (colit, altus)" (1979: 157). Vejase, também, o capítulo I de Bosi (1994: 11-63).

52 Segundo De Martino, deixando delado o pressuposto dogmático de um "mundo decidido e garantido" como o único possível, e de um ser dado deste mundo como a única forma de realidade que a presença possa experimentar, e, ainda, percebendo a extrema violência desses pressupostos.

53 Qualquer interferência cultural na relação com aalteridade que está além da linha interferindo necessariamente na contraparte.

54 Com este "esserci", que traduzimos enquanto "ser-no-lugar", 0 autor italiano traduzia o verbo "ser" que se refere ao homem na sua dimensão existencial dada (e historicamente determinada), expressa pelo advérbio " “" e, de alguma forma, ligada à dimensão existencialista expressa pelo filósofo alemão Martin Heidegger com o termo D a-Sein. Trata-se de conotar uma dimensão histórica e existencial da cultura (e de seus indivíduos) que se percebe nessa dimensão histórica e no seu estar presente (atuando) nela ou, no caso dramático contemplado pela citação, que se sente exposta ao risco de uma "presença não garantida" e precária.

\section{Bibliografia}

AGNOLIN, A.

19980 apetite da antropologia. 0 sabor antropofágico do saber antropológico: alteridadee identidade no caso T upinambá, São Paulo, tese, FFLCH-USP. 
2000

"A razão tênue de Montaigne", in MONTAIGNE, M. de. E nsaios, São Paulo, Martins Fontes, pp. XXI-XXXIII.

ARCAND, B.

1995 Il G iaguaro eil formichiere, Milão, Garzanti. [L ejaguar et le tamanoir, Toronto, Boréal, 1991.]

BARTHES, R.

1961

"Pour une psycho-sociologie de l'alimentation contemporaine", A nnales, vol. XVI: 977-86.

1982 Mitológicas, 5. ed., São Paulo, D ifel. [Mythologies, Paris, Seuil, 1957.]

BAUD RILLARD , J.

1996 A troca simbólica ea morte, São Paulo, Loyola. [L 'échange symbolique et la mort, Paris, Gallimard, 1976.]

BONNASSIE, P.

1989 "Consommation d'aliments immondes et cannibalisme de survie dans l'O ccident du Haut Moyen Age", A nnales, set.-out., n. 5: 1035-56.

BOSI, A.

1994 D ialética da olonização, 2. ed., São Paulo, Companhia das Letras.

BRELICH, A.

1966 Introduzione alla storia delle religioni, Roma, Ateneo.

1969 Paides e parthenoi, Roma, Ateneo.

1979 Storia delle religioni: perché?, Nápoles, Liguori.

CLASTRES, P.

1995 Crônica dos índios G uayaki, São Paulo, Editora 34. [C hronique des indiens guayaki, Paris, Plon, 1972.]

1990 A sodiedade ontra o E stado, trad. T. Santiago. Rio de Janeiro, Francisco Alves. [L a societé contre l'état: recherces d'anthropologie politique, Paris, Minuit, 1974.]

DE MARTINO,E.

1975 Morte e pianto rituale nel mondo antico, Turim, Boringhieri. 
1977 L a finedel mondo: contributo all'analisi delleapocalissi culturali, Turim, Einaudi.

1980 Furore, simbolo, valore, Milão, Feltrinelli.

1986 Il mondo magico: prolegomeni a una storia del magismo, Turim, Boringhieri.

DETIENNE, M.

1987 D ioniso ela pantera profumata, Roma, Laterza. [D ionysos mis à mort, Paris, Gallimard, 1977.]

DOUGLAS, M.

1976 Pureza eperigo, São Paulo, Perspectiva. [Purity and danger: an analysis of conoepts of pollution and taboo, Londres, Routledge and Kegan Paul, 1966.]

1979 I simboli naturali, Turim, Einaudi.

ELIAS, $N$.

1939 Ü ber den Prozess der Zivilisation, vol. I, Basiléia, Haus zum Falken.

FERNANDES, F.

1970 A função social da guerra na sociedade tupinambá, São Paulo, Livraria Pioneira.

1989 A organização social dos tupinambá, São Paulo, Huicitec/ UnB.

GIARD, L.

1996 "Fazer a cozinha", in CERTEAU, M. de, GIARD, L. \& MAYOL, P. (orgs.), A invencão do cotidiano. H abitar e cozinhar, v. 2, Petrópolis, Vozes.

HARRIS, M.

1977 Cannibals and king: the origins of alture, New York, Random House.

1985 G ood to eat: riddles of food and culture, New York, Simon and Schuster.

HARTOG, F.

1980 L e miroir d'hérodote: essais sur la représentation de l'autre, Paris, Gallimard.

HOLLAND A, S. B. DE

1994 Caminhos e fronteiras, São Paulo, Companhia das Letras.

LANTERNARI, VITTORIO

1974 L a grandefesta: vita rituale e sistemi di produzione nelle società tradizionali, Turim, Einaudi. 
LEACH, E.

1964

"Anthropological aspects of language: animal categories and verbal abuse", in LENNEBERG, E. H. (org.), $\mathrm{N}$ ew directions in the study of language, Cambridge, Mass.

LESTRINGANT, F.

1994 L e Cannibale: grandeur et décadenoe, Paris, Perrin.

LÉVI-STRAUSS, C.

1967a A ntropologia estrutural, Rio de Janeiro, Tempo Brasileiro. [A nthropologie structurale, Paris, Plon, 1964.]

1967b D u miel aux cendres, Paris, Plon.

1968 L 'origine des manières de table, Paris, Plon.

1974 "Introdução", in MAUSS, Marcel, Sociologia e A ntropologia, São Paulo, Pedagógica Universitária/ Edusp.

1991 Il crudo e il ootto, Milão, Mondadori. [L e cru et le ait, Paris, Plon, 1964.]

LOT-FALCK, E.

1953 L es rites de chasse chez les peuples sibériens, Paris.

MASSENZIO, M.

1994 Sacro e identità etnica: senso del mondo e linea di confine, Roma, Franco Angeli.

MELIÁ, B.

1981 “El 'modo de ser' guaraní en la primera documentación jesuítica (15941639)”, Revista deA ntropologia, vol. 24: 1-24.

MENGET, P.

1993

"Notas sobre as cabeças mundurucu", in CASTRO, E. V. de \& CUNHA, M. C. da (orgs.), A mazônia: etnologia ehistória indígena, São Paulo, Núcleo de História Indígena e do Indigenismo da USP/ FAPESP.

MÉTRAUX, A.

1971 Religioni e riti magii indiani nell'A merica M eridionale, Milão, Il Saggiatore. [R eligions et magies indiennes d'A mérique du Sud, Paris, G allimard, 1967.] 
POMPA, C.

1981

"Il mito della 'Terra senza Male': aspetti del profetismo tupi-guarani”, in POMPA, C., MAZZOLENI, G \& \& SANTIEMMA, A. (orgs.), L 'A merica rifondata: analisi di tre risposte indigene all'O cocidente, Roma, La G oliardica.

REMOTTI, F.

1996 Contro l'identità, Roma/ Bari, Laterza.

ROUSSEAU, G. S.

1995 "Uma ciência do canibalismo", in ALFO NSO-GO LD FARB, A. M. \& MAIA, C. A., H istória da ciência: o mapa do conhecimento, São Paulo, Edusp.

SABBATUCCI, D.

1965 Saggio sul misticismo greo, Roma, Ateneo.

1975 L o Stato come C onquista Culturale, Roma, Bulzoni.

1978 Il mito, il rito e la storia, Roma, Bulzoni.

SAHLINS, M.

1976

"La pensée bourgeoise", in Cultureand practical reason, Chicago, University of Chicago.

1987 Islands of history, Chicago, University of Chicago Press.

TAMBIAH, S. J.

1995 Rituali e Cultura, Bolonha, Il Mulino. [Culture, thought, and social action: an anthropological perspective, Cambridge, Harvard University Press, 1985.]

VALERI, R.

1977 Alimentazione, in E nciclopedia E inaudi, vol. I, Turim, pp. 344-61.

VIVEIROSDE CASTRO, E.

1986 A raweté: os deuses canibais, Rio de Janeiro, Jorge Zahar.

1992 "Apresentação", in VILAÇA, A., Comendo omo gente, Rio de Janeiro, Editora da UFRJ, p. XVIII.

VIVEIRO SDE CASTRO, E. \& CARNEIRO D A CUNHA, M.

1986 "Vingança e temporalidade: os tupinambá", A nuário A ntropológico/ 85, Tempo Brasileiro. 


\title{
Fontes
}

\author{
ABBEVILLE, C. D'. \\ 1975 H istória da missão dos padres capuchinhos na Ilha do Maranhão e terras ciraunvizinhas, \\ trad. de S. Milliet, São Paulo, Edusp. \\ CARDIM, F. \\ 1980 \\ "D o princípio e origem dosíndios do Brasil e de seus costumes, adoração \\ e cerimônias", in Tratados da terra e gente do Brasil , São Paulo, Itatiaia/ \\ Edusp.
}

GARZONI, T.

1587 L a piazza universale di tuttele professioni del mondo, Veneza, G. B. Somasco.

LÉRY, J. DE.

1980 V iagem à terra do Brasil, São Paulo, Edusp, 1980. [H istoire d'un voyage faict dans la terre du Brésil, Paris, Alphonse Lemerre, 1880, 2 v.]

MONTAIGNE, M. DE.

1987 E nsaios, Brasilia, UnB/ Huicitec. [E ssais, Paris, Gallimard, 1950.]

MONTEIRO, J.

1949 "Relação da Província do Brasil", in LEITE, S. (org.), H istória da C ompanhia. deJesus no Brasil , v. VIII, Rio de Janeiro, Instituto Nacional do Livro, pp. 393-425.

MUSTOXIDI, A.C.

1820 L enove muse di E rodoto alicarnasseo, tomo I, Milão. (Tradução e ilustração.)

SOUZA, G.S.DE

1971 Tratado descriptivo do Brasil em 1587, São Paulo, Edusp.

STADEN, $\mathrm{H}$.

1974

D uas viagens ao Brasil, São Paulo, Edusp. 
THEVET, A.

1880

"La cosmographie universelle", in LÉRY, J. de. H istoire d'un voyagefaict dans la terre du Brésil, Paris, Alphonse Lemerre.

1953a "Les français en Amérique pendantla deuxièmmemoitiédu XVIe. Siecle", in L e Brésil et les brésiliens, Paris.

1953b "Histoire d'André Thevet, Angoumoisin, cosmographe du roi, de deux voyages par lui faits aux Indes Australes et O ccidentales", in L e Brésil et les brésiliens, Paris. 
ABSTRACT: Human nutrition is a cultural datum with the same relevance at least as the merely and simply alimentary datum. G iving particular attention to the relationship between cultural datum and alimentary/ "natural" datum, this article considers a very uncommon food, the man. The man becomes, in a highly ritualistic structure, food for another man, who his turn lives in the prospect, highly significant for his culture, to become himself food for other man one day. D ue to the fact that Anthropology recognizes the importance of the cultural datum related to human nutrition, it becomes an essential prospect of analysis. On the other hand, alimentary paradigms themselves will be the outline of the critical study about the characteristic of comprehension/ digestion of the cultural difference by Anthropology.

Furthermore, putting ritual ("holy") anthropophagy at the centre of our work, we are obliged to adopt the historical-religious methodology of study point of view. The usefulness of this prospect of analysis is completely contained in the adjective "ritual", that is related to this specific form of anthropophagy. Consequently we have to clarify these terms/ concepts - to which the historicalreligious school dedicated big attention - , many times assumed without criticism, giving a appreciable contribution to contemporary historical and anthropological studies.

Therefore this text intends to analyse anthropophagy in the New World during the XVI and XVII centuries, related to an anthropological prospect of study and examined through a methodology of research, i. e. History of Religions. As far as this debate concerns, we refer to the "Italian School of History of Religions", recognizable in the pioneering work of Raffaele Pettazzoni and profitably camied on by Brelich, De Martino, Lanternari, Sabbattucci, Massenzio.

KEY-WORD S: Tupi Cultures, Anthropophagy, History of Religions, sacrifice, rituality, logic of mith, ritualistic exchange. 